\title{
RASGOS DEL MAGISTRAL GONZÁLEZ DE CANDAMO EN LA METROPOLITANA DE MÉXICO (1799-1804)
}

\author{
POR \\ Antonio Astorgano ABAjo \\ Universidad de Zaragoza \\ aastorganoa@telefonica.net
}

Para los amigos tapatíos Tomás de Híjar y María Palomar.

\begin{abstract}
RESUMEN
El teólogo ilustrado Gaspar González de Candamo (1753-1804) fue canónigo regular de San Agustín, magistral de la Colegiata de San Isidoro de León, catedrático de hebreo de la Universidad de Salamanca, canónigo por designación real de Guadalajara (México), gobernador eclesiástico de la diócesis del Nuevo Reino de León (Monterrey) y magistral de la Catedral Metropolitana de México. Partidario convencido de las reformas de los políticos del reinado de Carlos III, en el presente estudio presentamos sus andanzas en el cabildo de México. Excelente orador sagrado, analizamos brevemente el reformismo regalista de su pensamiento sociopolítico y religioso (cercano al jansenismo) a través de sus sermones.
\end{abstract}

PALABRAS CLAVE: Oratoria sagrada, Candamo, canónigo magistral, reformismo ilustrado, elogio fúnebre, Catedral Metropolitana de México, Núñez de Haro, Sánchez Leñero.

\section{TRAITS OF PERSONALITY OF THE MASTER CANON GONZÁLEZ DE CANDAMO AT METROPOLITAN CATHEDRAL OF MEXICO (1799-1804)}

\begin{abstract}
The Enlightenment theologist Gaspar González de Candamo (1753-1804) was a regular canon of San Agustín, and master as well of the Basilica of San Isidoro de León. He became a Hebraist doctor at the University of Salamanca, canon by royal designation of Guadalajara (Mexico), ecclesiatic governor in the diocese of the New Kingdom of León (Monterrey) and master of the Metropolitan Cathedral of Mexico. Enthusiastic advocate of political reforms of the reign of Carlos III, in this study we present his adventures in the council of the city of Mexico. Excellent orator brief discussion of their sociopolitical reformism and religious thought (close to Jansenism) through his sermons.
\end{abstract}

KEY WORDS: Sacred Oratory, Candamo, master canon, elightenment reformism, funeral praise, Metropolitan Cathedral of Mexico, archbishop Núñez de Haro, Sánchez Leñero.

Recibido/Received 02-06-2011

Aceptado/Accepted 16-10-2014

\section{INTRODUCCIÓN}

Mucho es lo que hay todavía que investigar sobre la amistad entre Meléndez Valdés y los poetas menores de la Escuela Salmantina, de la que Batilo fue maestro. Entre esos amigos, más o menos desdibujados por el olvido o la falta de datos históricos, está Gaspar González de Candamo (1753-1804), el que más confianza personal le inspiraba al poeta extremeño durante la etapa en que ambos estuvieron ligados a la Universidad de Salamanca (1775-1786), como demuestra la desgarradora Epístola V. Al Doctor Don Gaspar González de Candamo, Catedrático de Lengua Hebrea de la Universidad de Salamanca, en su partida a América de canónigo de Guadalajara de México, escrita entre noviembre de 1786 y junio de 1787, dedicada al «dulce Candamo, su tierno amigo ${ }^{1}{ }^{1}$ Por razones obvias de espacio, solamente

\footnotetext{
1 Meléndez Valdés, J. 2004: 657-663.
} 
podemos esbozar aquí sus andanzas por México capital (1799-1804), y remitir a otros estudios nuestros, ${ }^{2}$ para conocer la biografía del canónigo asturiano y sus relaciones con Jovellanos y Meléndez Valdés, aspecto este último muy relevante para nosotros. ${ }^{3}$

Gaspar González de Candamo (Santiago de Pruvia, Concejo de Llanera, Oviedo, diciembre de 1753-México, 16 de mayo de 1804) fue teólogo, canónigo regular de San Agustín, catedrático de Hebreo de la Universidad de Salamanca, canónigo de Guadalajara (México), gobernador de las diócesis de Monterrey y Guadalajara y magistral de la Metropolitana de México.

Tres son las fuentes para conocer su vida: el archivo de la Universidad de Salamanca, a la que estuvo ligado desde 1775 hasta 1786 como alumno y catedrático, el currículum que el mismo Candamo presentó en la última oposición en la que participó (1797) y la emotiva Oración fúnebre que, a su muerte (1804), pronunció el catedrático de Filosofía Moral de la misma universidad, Miguel Martel, posteriormente diputado anillero a Cortes por Salamanca desde 1820 hasta 1822. ${ }^{5}$ Entre los estudiosos modernos, sólo Gabriela Zayas se ha acordado de nuestro personaje ${ }^{6}$ y más recientemente nosotros. $^{7}$

Se distinguen dos etapas claras en la trayectoria vital de Candamo, separadas por la decisión de emigrar a México en 1787, si bien en la misma podemos hacer varias sub-etapas, algunas de las cuales se solapan: 1ạ. Infancia y niñez (17531765). 2a. Estudios en la Universidad de Oviedo (17651773). 3a. Canónigo magistral en la Colegiata de San Marcos de León (1773-1775). 4ạ. Estudiante de Teología y catedrático de Hebreo (1775-1786). 5a . Canónigo de Guadalajara (1787-1799). 6á. Gobernador eclesiástico de la actual diócesis de Monterrey (1790-1792). 7ạ. Canónigo magistral de la Metropolitana de México (1799-1804).

No vamos a detenernos en la narración de estas siete etapas. Sólo lo haremos brevemente en la última, para esbozar su sincero reformismo regalista en tierras americanas, consecuencia de la misma actitud vital de su lucha contra el inmovilismo de la Universidad de Salamanca, donde había sido catedrático de hebreo.

2 Además de en este trabajo, hemos estudiado diversos aspectos de la figura de González Candamo en Astorgano Abajo, A. 2011-1: 365386; Astorgano, A. 2011-2: 13-70; Astorgano, A. 2012-1: 1257-1322; Astorgano, A. 2012-3; Astorgano, A. 2013-1: 321-408; Astorgano, A. 2014: 13-112.

3 Astorgano Abajo, A. 2007: 342-345.

4 González de Candamo, G. 1797-1. Relación impresa de méritos y ejercicios literarios del Dr. D. Gaspar González de Candamo, fechada en México el 2 de agosto de 1797. Son ocho hojas, conservadas en el Archivo General de la Nación de México (en adelante AGN), Indiferente Colonial, Caja 2182, Exp. 34, ff. 12-16.

5 Martel, M. 1805. Ejemplar en la Biblioteca Nacional de Madrid, Siglo XVIII, caja 378, número 35. Sobre este catedrático de Filosofía Moral de la Universidad de Salamanca y diputado liberal, véase García Pérez, A. 2002; García Pérez, A. 2013.

6 Zayas de Lille, G. 1985: 13-23; Zayas, G. 1991: 266-408.

En concreto, para una visión panorámica, en Astorgano, A. 2011-1. Para la etapa salmantina, Astorgano, A. 2013-1. Para la etapa asturiana, Astorgano, A. 2011-2, y para las etapas en Nueva España, Astorgano, A. 2012-1.

\section{ETAPAS MEXICANAS DE CANDAMO (1787-1804)}

Las etapas mexicanas de Candamo abarcan los últimos 17 años de su vida (1787-1804), periodo de enormes y variados cambios en el virreinato. El clérigo ilustrado Candamo aterriza en Nueva España (primavera de 1787) cuando el que será su amigo, el arzobispo Núñez de Haro, acababa de asumir interinamente el virreinato y cuando el sistema hacendista del visitador y posterior Ministro de Indias, José Gálvez, basado en las intendencias, entra en crisis por la muerte de su impulsor (17 de junio de 1787). Un periodo en el que el criollismo estaba en auge tanto ideológica, como administrativamente, con personajes como el influyente regente de la Real Audiencia de México, Francisco Javier Gamboa (1788-1794), que torpedeaban silenciosamente la política madrileña. ${ }^{8}$ Desde Italia los desterrados jesuitas llevaban desde principios de la década de 1780-1790 alimentando un sentimiento de patriotismo mexicano (por ejemplo, Francisco Javier Clavijero con Historia Antigua de México, [1780] o Rafael Landívar con Rusticatio Mexicana [1781]), incluso con la comprensión del fiscal de Indias, José Cistué. ${ }^{9}$ Entre tanto una serie de medidas financieras y de distintos tipos fueron dadas por el gobierno de Madrid, muchas veces forzado por las circunstancias convulsas que ocasionaron la Revolución Francesa, las Guerras napoleónicas y las prácticas corruptas de algún virrey como el marqués de Branciforte (1794-1798), que exacerbarían al criollismo hasta hacer estallar el descontento preindependentista. Meses después de la muerte del magistral asturiano, a finales de 1804, se publica el decreto de consolidación de vales reales, que significó un desastre para la economía del virreinato.

A juzgar por el Elogio fúnebre de Martel, Candamo desarrolló una eficaz y agotadora actividad en los obispados de Guadalajara, Monterrey y México. En efecto, el canónigo asturiano pudo desenvolverse bastante bien en este ambiente cada vez más antiespañol, gracias a que tuvo la suerte de contar con el respaldo de tres obispos muy notables: fray Antonio Barriga ${ }^{10}$ y Juan Cruz Ruiz de Cabañas, ${ }^{11}$ en Guadalajara, y de Alfonzo Núñez de Haro en México.

Según la cronología propuesta por nosotros la aventura mexicana de Candamo abarca las tres últimas fases de su vida: 5a. Canónigo de Guadalajara (1787-1799). 6ạ. Gobernador eclesiástico de la actual diócesis de Monterrey (1790-1792). 7ạ. Canónigo magistral de la Metropolitana de México (17991804). Lógicamente Gaspar en su currículum de 1797 sólo puede narrarnos lo que le ocurrió hasta ese año:

"Fue presentado por el rey nuestro señor para una canonjía de gracia de la Santa Iglesia Catedral de Guadalajara, de la que tomó posesión el día 20 de agosto de 1787.

\footnotetext{
8 Trabulse, E. 1985: 138-149.

9 Astorgano, A. 2009: 201-254.

10 Fallecido en 1792 a los 91 años, el anciano obispo Alcalde y su cabildo pronto nombraron a Candamo "juez hacedor de las rentas decimales", es decir controlador de las finanzas del obispado. Dávila Garibi, J. I. 1963: 899-1048; Híjar Ornelas, T. 2003.

11 Dávila Garibi califica a Ruiz de Cabañas de "gran prelado". Dávila Garibi, J. I. 1963: 1079-1160; Dávila Garibi, J. I. 1984.
} 
El muy ilustre señor deán y cabildo de dicha Santa Iglesia [de Guadalajara, México] le nombró juez hacedor de las rentas decimales, ${ }^{12}$ cuyo cargo está ejercitando en la actualidad [1797].

Tiene licencia del Ilmo. Señor Don Fray Antonio Alcalde, obispo de esta diócesis [Guadalajara, fallecido en agosto de 1792], para predicar y confesar a hombres y mujeres, inclusas las monjas.

Hizo oposición en el año pasado de 1789 a la canonjía lectoral de esta Santa Iglesia metropolitana [de México], habiendo leído una hora con puntos de 24 , respondido a dos argumentos de media hora, y argüido por el mismo espacio de tiempo a sus coopositores, y predicado una hora con puntos de 48 sobre el Evangelio que le cupo en suerte, $y$, en la consulta que el excelentísimo señor Arzobispo y Venerable Señor Deán y Cabildo hicieron al rey nuestro señor, tuvo varios votos en primero, segundo y tercero lugar.

Igual oposición hizo a la canonjía magistral vacante en la misma Santa Iglesia Metropolitana [de México] el año de 1790 , en cuya consulta obtuvo dos votos en primer lugar, cuatro de segundo y dos en tercero.

Por nombramiento del excelentísimo señor arzobispo de México, confirmado por el rey nuestro señor (que Dios guarde), ha sido gobernador del Obispado del Nuevo Reino de León en la última sede vacante [1790-1792], ${ }^{13}$ por falta de Cabildo, y visitó lo más de su dilatado y penoso obispado a satisfacción de su Excelencia [el arzobispo Núñez de Haro].

Fue nombrado por el IImo. Venerable Señor Deán y Cabildo de Guadalajara sede vacante ${ }^{14}$ para tomar posesión de las provincias de la Barca, Zapotlán y Colima, nuevamente agregadas a aquella mitra, y ejercer en ellas, como efectivamente ejerció [en el verano de 1795], todas las facultades ordinarias.

Es gobernador actualmente [1797] del obispado de Guadalajara por nombramiento de su ilustrísimo prelado [Juan Cruz Ruiz de Cabañas], a cuya satisfacción está desempeñando este cargo. ${ }^{15}$

Finalmente hizo oposición a la canonjía magistral actualmente vacante en esta Santa Iglesia Metropolitana de México". ${ }^{16}$

Subrayemos que desde 1796 convivió en Guadalajara con el obispo Juan Cruz Ruiz de Cabañas y Crespo (Espronceda, Navarra, 1752-Estancia de los Delgadillos, México, 1824), antiguo compañero de estudios en la Universidad de Salamanca, quien lo nombró gobernador del obispado. ${ }^{17}$ Nacido un año antes que Candamo, después de opositar a

12 Las rentas decimales eran la mayor fuente de ingresos de la Iglesia española en el siglo XVIII. Es importante el conocer el sistema tributario de los diezmos, una de las razones por las que se le nombró para gobernador, sede vacante, del obispado del Reino de Nuevo León, donde el anterior gobernador, Antonio Bustamante, canónigo de Puebla, en la precedente sede vacante (1780-1783) había dejado un desfalco de más de 150.000 pesos, dando lugar a un prolongado pleito.

13 A la muerte del obispo franciscano Rafael Verger, a principios de julio de 1790.

14 Candamo ejerció esta recepción después del fallecimiento del obispo Esteban Lorenzo de Tristán y Esmenota (4 de abril a 10 de diciembre de 1794), y antes de que comenzase el mandato de Juan Cruz Ruiz de Cabañas y Crespo (1796-1824).

15 El obispo Ruiz de Cabañas ingresó en Guadalajara el 3 de diciembre de 1796, por lo tanto González de Candamo fue gobernador por mandato suyo desde 1797 hasta mayo de 1799, en que tomó posesión de la magistralía en México.

16 González de Candamo, G. 1797.

17 Astorgano, A. 2012-1. algunas canonjías en las catedrales de Palencia, Valladolid, Jaén y Badajoz, consiguió, finalmente, la magistralía de la seo de Burgos en 1784, gracias a la recomendación del inquisidor general Agustín Rubín de Ceballos. ${ }^{18}$ Por su parte, el asturiano sólo cosechaba fracasos en sus oposiciones a cátedras de teología en Salamanca y a la magistralía de Oviedo (1783). ${ }^{19}$ Ambos eran conscientes de la importancia de la educación para la consecución del progreso y creían que la Iglesia debía contribuir en la búsqueda de los medios para la consecución de la felicidad de las gentes. Si Candamo, siendo gobernador eclesiástico de Nuevo León (1790-1792), antepuso la creación de un seminario a la edificación de la catedral e incluso a la constitución del cabildo, Ruiz de Cabañas, por su parte, se aplicó decididamente a fomentar la formación del clero, para lo cual creó el Seminario Conciliar de San José y el Colegio clerical del Divino Salvador, dotándoles de útiles estatutos y programas de estudio muy completos, convirtiéndose en potentes motores para el desarrollo de la zona. ${ }^{20}$

\section{CANDAMO, MAGISTRAL DE LA CATEDRAL DE MÉXICO (1799-1804)}

Como de esta etapa Candamo no pudo decir nada en su currículum de 1797, debemos fiarnos del panegírico de Martel y de la reseña de José Mariano Beristáin de Souza, ilustre bibliófilo, que le dedicó una elogiosa entrada a su amigo Candamo en la Biblioteca Hispanoamericana Septentrional:

“Candamo (Don Gaspar González). Natural del Principado de Asturias, doctor teólogo, catedrático de lengua hebrea en la universidad de Salamanca. Un desaire que creyó habérsele hecho por un cabildo eclesiástico en España en la votación de una prebenda de oficio [magistralía de Oviedo en 1783] lo trajo a la España Nueva con una canonjía de la catedral de Guadalajara en la Nueva Galicia. Dos veces intentó colocarse en el coro de México, haciendo oposición escolástica a sus prebendas lectoral [1789] y magistral [1790], pero no lo consiguió hasta en la tercera, en que volvió a vacar esta última [1796], y consultado con todos los votos por el cabildo metropolitano, fue nombrado canónigo magistral. Sirvió algún tiempo la capeIlanía mayor del Convento de Capuchinas de esta capital, ${ }^{21}$

18 Ruiz de Cabañas fue consagrado obispo de Nicaragua el 19 de abril de 1795 por el arzobispo de Toledo, Francisco Antonio Lorenzana, y el 18 de diciembre del mismo año fue trasladado a Guadalajara. Véanse también sobre este asunto, Romero Delgado, J. 1991: 29-39; Gutiérrez Lorenzo, Mạ P. 2006: vol. I, 397-418, 401, y Melgosa Oter, O. R. 2010: 661-695.

19 Cfr. Astorgano, 2013-1.

20 AGI, Guadalajara 543. Estado material y formal de la diócesis de Guadalajara en el año 1805, por su obispo Juan Cruz Ruiz de Cabañas. Analizado por Romero Delgado, 1991: 22-28; Raúl Melgosa, O. R. 2010: 666-667.

21 Cuando Beristáin menciona que Candamo era capellán de "las capuchinas de México", hay que tener en cuenta que éstas no sólo tenían un convento en la ciudad, sino también otro (fundado precisamente por Núñez de Haro) en la villa de Guadalupe, que dadas las comunicaciones de la época quedaba relativamente lejos (el trayecto no llevaría menos de unas tres horas), lo cual quizás explique en parte las ausencias de Candamo de las juntas de Cabildo, si es que el magistral asturiano se encargó del más alejado. 
pero su quebrantada salud lo obligó a renunciarla; y a pocos días desapareció repentinamente de entre los vivos, cuando en la Corte se le preparaba una Mitra, como premio de su exquisita literatura, de sus recomendables prendas y del acierto con que había gobernado el obispado del Nuevo Reino de León. Escribió: Elogio de Carlos III, Rey de las Españas, predicado en las Honras que se celebraron el día 28 de julio de 1789, en la catedral de Guadalajara. Impreso en México dicho año. Elogio fúnebre del Exmo. e IImo. Sr. D. Alonso Núñez de Haro y Peralta..., Impreso allí [en México], 1801, en $4 .^{\circ \prime \prime 22}$

Por su parte, el panegírico de Martel es menos preciso, aunque define los cinco años de la magistralía de México, como "la más brillante y más laboriosa de su vida", lo cual se contradice, en cierta medida, con su débil salud. ${ }^{23}$

Lo que parece claro es que la última etapa vital de Candamo fue la más espiritual de un virtuoso, paciente y afanoso magistral, pues aunque Martel dice que "despachó una multitud de informes y consultas de toda especie", no debían ser de excesiva importancia, ya que no aparecen reflejados en las actas del Cabildo:

"El Señor Candamo entró en México debilitado ya, sin embargo de su constitución robusta, en fuerza de sus trabajos en el gobierno de la Nueva León [1790-1792], y de su meditación y estudio, que jamás conocieron la interrupción y el descanso. El Señor Arzobispo de aquella Metrópoli le encarga inmediatamente la dirección de las Religiosas Capuchinas $^{24}$ de su capital. [...] El Señor Candamo, débil ya y extenuado, se niega a todo descanso y comodidad, aun a la más conforme a sus ideas, a la comunicación de sus amigos; y vive entregado, sin reserva, a las más serias y religiosas ocupaciones". 25

Por el examen de las actas de los cabildos de la Metropolitana, sabemos que con frecuencia los abandonaba para atender sus funciones litúrgicas y pastorales, siendo literalmente cierta la afirmación de Martel: "Desde su casa al coro, desde este al confesonario, desde aquí a la lectura de los libros santos y al despacho de una multitud de informes y consultas de toda especie". ${ }^{26}$

LA OBSESIÓN DE CANDAMO POR GANAR UNA CANONJÍA DE OFICIO EN LA METROPOLITANA DE MÉXICO

Candamo se sentía, ante todo, un competente teólogo con vocación de magistral, como demuestran las repetidas veces que opositó a una cátedra de teología de la universidad de Salamanca, haber ganado la canonjía de la Colegiata de San Isidoro de León con solo veinte años (1773) y haber participado en la oposición a la magistralía de Oviedo (otoño de 1783), a pesar de querer prohibírselo el obispo González Pisador. ${ }^{27}$ Por otro lado veía que otros compañeros, como Ruiz de Cabañas, con igual o menor formación, pero con mayores padrinazgos, estaban consiguiendo oficios en

\footnotetext{
22 Beristáin de Souza, J. M. 1816: vol. II, 36.

23 Martel, M. 1805: XXIX.

24 Arenas Frutos, I. 2004.

25 Martel, M. 1805: XXX-XXXI.

6 Ibídem: XXXI-XXXII.

7 Astorgano, A. 2013-1: 321-408.
}

diversas catedrales, mientras que él parecía condenado a eternizarse en una cátedra menor, la de hebreo. Zayas habla del carácter ambicioso de Candamo, causa por la que emprendió la aventura americana cuando se le ofreció la oportunidad de una canonjía de oficio en Guadalajara. Pero no dejaba de ser una canonjía menor (unos 600 o 700 pesos de dotación), frente a una canonjía de oficio (más de 4.000 , según la rentas de cada catedral). Por eso, consciente de su valía y formación académica, desde que puso pie en la Nueva España no cejó hasta conseguir la magistralía de la catedral más importante de América, la Metropolitana de México, que solo pudo disfrutar cuando ya contaba con más de 46 años (mayo de 1799). Cuando falleció en mayo de 1804 el canónigo asturiano era un candidato firme para un obispado, consiguiendo lo que su colega (de estudios de Teología, de oposiciones y de la misma edad) Ruiz de Cabañas hacía muchos años había conseguido (la magistralía de Burgos en 1784 y el obispado en 1793).

Pero nadie le iba a regalar nada a Candamo en la Nueva España. Seguramente esa diferencia de sueldos y el deseo de progresar "profesionalmente" fueron la causa de su constante estudio ("la lectura de los libros santos", de que habla Martel) y lo que lo llevaron a opositar muy pronto para conseguir una de las canonjías de oficio, no en vano sabemos que Candamo buscaba en América su "fortuna". Concursó para la lectoral de la catedral de México en 1789 y para la magistral de la misma en 1790. Ambas las perdió, a pesar de exhibir sus profundos conocimientos de las Sagradas Escrituras y de Historia de la Iglesia. Demostró su valía personal, de manera que el arzobispo Alonso Núñez de Haro lo designará gobernador de la mitra vacante en el Nuevo Reino de León (Monterrey) en 1790, y cuando vuelva a quedar vacante la magistral de México, el cabildo se la asignará por unanimidad (1797).

La ciudad de México, capital virreinal y sede del arzobispado, fue un lugar idóneo para hacer una carrera de altos vuelos en la Iglesia y sus instituciones. Pero no era fácil para los clérigos integrarse en ellas, pues debían contar con los méritos suficientes y las relaciones necesarias para tener éxito. Según Rodolfo Aguirre, lo que más caracterizó al clero en ascenso de México, y de lo que dependía su fama y distinción, fue su capacidad de construir relaciones fundamentalmente con la jerarquía del arzobispado, cabildo y arzobispo, aunque también con otras instancias de gobierno y de poder, como el Virrey, la Audiencia, el Ayuntamiento o el Consulado de comerciantes. ${ }^{28}$

El desencantado catedrático de Hebreo de la Universidad de Salamanca que era Candamo en 1786, consiguió que Campomanes, aprovechando las magníficas relaciones de Carlos III con el obispo de Guadalajara, fray Antonio Alcalde, se le concediese una canonjía de gracia, pero tuvo que ganarse a pulso una canonjía de oficio en la catedral de México, pasando por la experiencia de dos suspensos, uno a la lectoral en 1789 y otro a la magistralía en 1790, porque la comunidad clerical mexicana estaba conformada por doctores clérigos, catedráticos y rectores de la universidad o los colegios, funcionarios de la curia o de la Inquisición

\footnotetext{
28 Aguirre Salvador, R. 2004-1: 182.
} 
y curas de la ciudad, que tenían sus reglas de ascenso y meritaje, que no estaban dispuestos a quebrantar. Sólo después de diez años (1787-1797) de duro trabajo en las diócesis de Guadalajara y Monterrey al servicio del arzobispo Núñez de Haro, pudo conseguir la ansiada magistralía. El que Candamo hubiese logrado la prebenda de canónigo de gracia de la catedral de Guadalajara directamente en Madrid, no le eximía del deber de ganarse la integración en el grupo dominante de la catedral de México, si quería seguir ascendiendo. ${ }^{29}$

\section{El cabildo metropolitano de México que conoció González de Candamo}

No procede que nos detengamos aquí a describir la composición y funciones del cabildo de México, perfectamente reguladas desde el III Concilio Provincial de México (1585) que elaboró, entre otros documentos, Los Estatutos de la Santa Iglesia de México, los cuales recibieron la doble aprobación pontificia (1589) y real (1591). Tampoco podremos detenernos en las biografías de cada uno de los miembros del cabildo, calificado por Iván Escamilla como "una fortaleza criolla", al retratar la vida del canónigo José Patricio Fernández de Uribe (1742-1796), a donde remitimos para hacernos una idea del contexto en que se desenvolvió la magistralía del canónigo asturiano. ${ }^{30}$

Recordemos que integraban el Cabildo Eclesiástico mexicano el deán (su presidente y árbitro de las sesiones), las cuatro dignidades (arcediano, chantre, maestrescuela y tesorero), los cuatro canónigos de oficio (doctoral, magistral, lectoral y penitenciario), los canónigos de merced y los prebendados racioneros y medios racioneros, que ocupaban sus asientos en el coro según un orden que databa de 1570, en tiempos del arzobispo fray Alonso de Montúfar.

Escamilla, a quien resumimos, ${ }^{31}$ ha subrayado el prestigio de los capitulares entre el pueblo, pues este "Senado Eclesiástico" no limitaba sus funciones al gobierno del Máximo templo de la sede mexicana: auxiliaba y aconsejaba constantemente en su labor pastoral al arzobispo, y a su cargo corría la recolección y administración de las riquezas que ingresaban como diezmos en las arcas de la Iglesia. En todas las ocasiones en que vacaba la sede, ya fuera por muerte o promoción de sus prelados (que no fueron pocas), tocaba al Cabildo ejercer provisionalmente el gobierno espiritual de tan inmensa diócesis. Lo anterior, sin tomar en cuenta las innumerables veces que el Cabildo envió al soberano representaciones en nombre tanto de la Iglesia mexicana como del reino entero.

29 En el antiguo régimen los grupos o colectivos eran más importantes que los individuos. Aguirre Salvador, R. 2008: 82.

30 Escamilla González, I. 1999: 94-131. La bibliografía sobre e cabildo mexicano es abundante. Mencionaremos, en primer término, los muchos trabajos que a este tema ha dedicado Rodolfo Aguirre Salvador, entre otros, Aguirre Salvador, R. 2003; Aguirre Salvador, R. 2004-1; Aguirre Salvador, R. 2004-2; Aguirre Salvador, R. 2008; Aguirre Salvador, R. 2007; Aguirre Salvador, R. 2010 y Aguirre Salvador, R. 2012. Para una visión general y a la vez detallada de los cabildos de México y Lima, puede consultarse Ganster, Paul. 1991.

31 Escamilla, I. 1999: 99-100.
La proyección del Cabildo de México hacia el virreinato era mayúscula, ${ }^{32}$ si advertimos que su organización había sido el modelo sobre el cual se habían estructurado los cabildos de las demás sedes sufragáneas de la Nueva España, desde la erección del obispado en 1534 y la promulgación de los Estatutos del Cabildo por el Tercer Concilio Provincial en $1585 .^{33} \mathrm{El}$ Cabildo, finalmente, era presencia importante de la vida pública de la capital del virreinato, igual en la recepción de las altas autoridades que en todas las ocasiones de regocijo o de llanto general. Sus miembros eran apreciados por los ricos y poderosos de la tierra, y fueron caritativos y estimados benefactores del pueblo.

La historiografía mexicana, en una gran parte anticlerical, no ha sabido explicar satisfactoriamente la contradicción que suponía el prestigio y el arraigo local que, según los testimonios de la época colonial, tenía el alto clero catedralicio, el cual se suponía que estaba dominado por los "opresores" peninsulares.

Las interesantes investigaciones de Paul Ganster sobre los cabildos de México y Lima han resuelto esta aparente contradicción. Ganster compiló la información existente acerca del origen de los capitulares de México y Lima a lo largo de todo el siglo XVIII y sus resultados fueron sorprendentes, pues echaron por tierra la suposición - uno de tantos mitos sobre las causas de la Independencia- de que la discriminación peninsular hacia los criollos se había extendido hasta la expulsión de éstos de las prebendas catedralicias americanas. ${ }^{34}$

En el caso mexicano, el promedio durante toda la centuria es de alrededor de un 70 por ciento de prebendados novohispanos y un 30 por ciento de peninsulares. Ni siquiera durante el periodo de las reformas borbónicas, en que la exclusión de los americanos era, según se sabe, una política explícita del gobierno de Madrid, se rompe el monopolio novohispano en el Cabildo. Como ejemplo, veamos las cifras de Ganster para el periodo 1770-1799:

\begin{tabular}{|c|c|c|}
\hline Años & Origen & Porcentaje \\
\hline \multirow{2}{*}{$1770-1779$} & Criollos & 68 \\
& Peninsulares & 32 \\
\hline \multirow{2}{*}{$1780-1789$} & Criollos & 65 \\
& Peninsulares & 35 \\
\hline \multirow{2}{*}{$1790-1799$} & Criollos & 70 \\
& Peninsulares & 30 \\
\hline
\end{tabular}

Canster averiguó también la ocupación de las familias de los capitulares criollos, y halló una gran diversidad: comerciantes, mineros, hacendados, burócratas menores, etcétera. ${ }^{35}$ En otras palabras, los grandes intereses novohispanos

32 Será el arzobispo mexicano Núñez de Haro, y no el virrey, quien en el verano de 1790 designe a Candamo como gobernador, sede vacante, de la diócesis de Monterrey.

33 Tanto la Erección de 1534 como los Estatutos de la Catedral de México de 1585 pueden verse en su original latino y en traducción castellana en la edición de Mariano Calvan Rivera y Basilio Arrillaga del Concilio III Provincial Mexicano.

34 Escamilla, I. 1999: 100-101.

35 Ganster, P. 1991: 153-154, 157; Escamilla, I, 1999: 101-102. 
estuvieron plenamente representados todo el tiempo en el Cabildo de México, el cual era, sin lugar a dudas, un vocero de las inquietudes de la oligarquía dentro de la alta jerarquía clerical. En conclusión, el Cabildo no era la Iglesia ajena y extranjera que erróneamente se ha dibujado por la historiografía liberal y anticlerical, que se fijaba exclusivamente en el origen de los obispos novohispanos que ciertamente, en su mayoría, era de origen peninsular.

Éste es un hecho fundamental que debemos tener en cuenta en adelante para acercarnos a nuestro magistral asturiano, que mantuvo sus vínculos con el grupo de "españoles", compaginados con una perfecta integración en la mayoría criolla del Cabildo. ${ }^{36}$

Sólo podemos aquí enumerar a los capitulares mexicanos que conoció el magistral asturiano, a través de sus oposiciones (1788-1799) y a través de los libros de actas catedralicias, a lo largo de los cinco años que ejercitó su magistralía (1799-1804). En el cabildo del 11 de agosto de 1797 se votó la canonjía magistral ganada por Gaspar González de Candamo en la cual ejercieron su voto el arzobispo Don Alfonso Núñez de Haro, y los canónigos, don Valentín García y Narro, deán; don José Serruto, arcediano; don José Ruiz de Conexares, tesorero; don Juan Francisco Campos, maestrescuelas; don Juan Mier y Villar; don Juan Antonio Bruno; don Pedro Valencia; don Juan José Gamboa; don Juan Francisco Jarabo y don José Mariano Beristáin. En dicha acta también se mencionan al fallecido magistral don Manuel de Omaña (que había vencido a Candamo en la oposición de 1790); al secretario del tribunal de la oposición don Manuel de Zubicueta; al "asistente real", nombrado por el virrey, don Juan Francisco Castañiza, marqués de Castañiza "y rector actual de la Real Universidad [de México]". Excusó su asistencia por enfermedad, el chantre don Manuel de Sandoval, quién delegó su voto en el lectoral don Juan Bruno. Firman el acta el arzobispo Núñez de Haro, el deán Valentín García y Narro y el "secretario del concurso", doctor Manuel Zubicoeta. ${ }^{37}$

En el cabildo del 18 de mayo de 1799 se anota la posesión de la magistralía por González de Candamo, y se nombraron por comisarios a los canónigos Dr. don Juan Mier y Villar y licenciado don Andrés Fernández Madrid, que serán los dos mejores amigos del asturiano dentro del Cabildo, junto con José Mariano Beristáin, en los que delegará su voto en las ausencias. ${ }^{38} \mathrm{~A}$ estos canónigos habría que añadir otros personajes importantes relacionados con la curia y la catedral, como el Dr. don Manuel Flores, secretario de Núñez de Haro y futuro biógrafo, y los prebendados de entera y media ración, como Fonterrada, Chaves, Sandoval, Villaurrutia, Barrio (el que dirá el elogio latino del arzobispo Núñez de Haro), Picó, Buchet y Gazano, muchos de los cuales terminarán ganando una canonjía, toda una burocracia eclesiástica, muy bien formada intelectualmente y con verdadera dedicación a su oficio. Una vez conseguida la prebenda, nadie podía dormirse en los laureles, ya que cada digni-

36 Escamilla, I. 1999: 102.

37 Archivo del Cabildo de la Catedral de México (ACCM), Año 1797, libro 59, ff. 117r-119v.

38 ACCM, Año 1799, f. 299. dad y cada canónigo de oficio tenía una función específica, administrativa o espiritual, en el gobierno catedralicio, ${ }^{39}$ además de la cotidiana celebración de la misa en la Catedral y la obligación de la continua asistencia al rezo de las horas canónicas en el coro. ${ }^{40}$

\section{Las reñidas oposiciones a las canonjías de la Metropolitana de México.}

Es comprensible que entrar en un cabildo eclesiástico fuese la más grande ambición de la mayoría de los clérigos novohispanos. Apenas vacaba una modesta prebenda en la sede episcopal más pobre, y se enviaban a las demás diócesis los edictos que convocaban a suplirla, cuando ya se arremolinaba una muchedumbre de capellanes, párrocos, profesores universitarios y burócratas eclesiásticos dispuestos a concursar. ${ }^{41}$ Para hacernos una idea, enumeraremos los coopositores contrincantes de Candamo en oposición a la canonjía lectoral (1789), a la magistralía que perdió en 1790 y a la misma canonjía que ganó en 1797.

Por lo que respecta a la oposición a la canonjía lectoral de la catedral de México (1789) concurrieron otros ocho opositores, además de Candamo: Juan María Vázquez, cura de Culhuacán; Antonio Venegas, de la parroquia de Santa Ana, de la capital; Ignacio Moreno, canónigo de la Colegiata de Guadalupe; José María Bravo, catedrático de filosofía de la universidad de México; el maestro Juan Antonio Bruno, cura de la parroquia de Santa Catarina; Joseph Eusebio Sánchez Bustamante, del obispado de Valladolid; Juan Francisco Castañiza, Colegial de San Ildefonso, ${ }^{42}$ y Feliciano Pablo Mendívil, catedrático del Seminario Tridentino.

Como de costumbre, Candamo perdió la oposición a la canonjía lectoral (1789) en la votación del cabildo, a pesar de que el informe presentado por el jurado dice: "y para la canonjía... el Dr. D. Gaspar González de Candamo, canónigo de merced de la Santa Iglesia de Guadalaxara... es sujeto digno de ella". En ese mismo informe aparece tachada la siguiente frase: "pero estimo más digno de ella al Dr. D.

39 Para el gobierno eclesiástico, los canónigos estaban obligados a la asistencia puntual a las sesiones del Cabildo, que tenían lugar los martes y viernes de cada semana. El "cabildo de tercia", como se llamaba a la sesión de los martes, se dedicaba únicamente a "negocios temporales", es decir, a todos los asuntos relacionados con los ingresos del Cabildo y la fábrica material de la Catedral. La reunión capitular de los viernes, o "cabildo de sexta", enfilaba sus trabajos a las "cosas espirituales", como lo referente al culto en el templo, los servicios en el coro, las costumbres de los capitulares y los problemas surgidos en la cotidiana observancia de los Estatutos. Como, por ejemplo, todo documento expedido oficialmente en nombre del Cabildo recibía las rúbricas de un dignidad, un canónigo, un racionero y un medio racionero. Véase Estatutos, 2a . parte, cap. I, § XIV, en ibíd., pp. LXXXVIII-LXXXIX y Estatutos del Cabildo, 2a. parte, cap. 1, §§ I, III y IV; Escamilla, I. 1999: 104-105.

40 Escamilla, I. 1999: 104. En las dos catedrales de Zaragoza hemos visto los minuciosos libros del prebendado multador para descontar una parte del salario por cada ausencia injustificada al coro.

41 Escamilla, I. 1999: 100.

42 Debemos recordar a Juan Francisco Castañiza, Colegial de San Ildefonso, futuro obispo de Durango, entre 1815 y 1825, hermano de jesuitas y favorecedor de esta Orden en México entre 1815 y 1825. Castañiza será el delegado del virrey Branciforte en la oposición a la magistralía de 1797, que ganará Candamo. 
Gaspar González de Candamo...". ${ }^{33}$ La canonjía fue adjudicada a Juan Antonio Bruno de la Ossa, el 21 de diciembre de 1789, según consta en la Gazeta de México. Como hemos visto, en el currículum citado de 1797, Candamo recordará esta oposición con bastantes detalles. ${ }^{44}$

A la magistralía de 1790 se presentaron once opositores, de los cuales siete ya habían participado el año anterior en la canonjía lectoral: el doctor y maestro don Manuel de Omaña, cura del Sagrario de esta santa Iglesia; el doctor don José Ignacio Carrasco, presbítero colegial en el de San Ildefonso; el doctor don Antonio Monteagudo, presbítero pro secretario del excelentísimo señor arzobispo; el doctor don Ignacio Ylsarbe, presbítero colegial en el Seminario; el doctor don Pedro Foronda, presbítero colegial en el mismo; el doctor don Feliciano Mendívil, diácono colegial en el mismo; el doctor don José María Alcalá, cura coadjutor del Sagrario de esta Santa iglesia; el doctor don Antonio Venegas, cura de de la parroquia de Señora Santa Ana; el señor doctor don Gaspar González Candamo, canónigo de la Santa Iglesia de Guadalajara; el doctor don Ignacio Ramón de Moreno, canónigo de idioma en la colegiata de nuestra Señora de Guadalupe; y el doctor y maestro don José María Bravo, presbítero de este arzobispado. ${ }^{45}$

La consiguió Manuel de Omaña y Sotomayor, hermano del entonces arcediano de la catedral, Salvador de Omaña, quien probablemente movió muchos hilos para beneficiar a Manuel. Candamo vio cortadas sus aspiraciones de ascenso porque todavía no estaba integrado en alguno de los ámbitos del poder eclesial idóneo para sus logros. ${ }^{46}$ Como señala Escamilla, aunque los méritos y trabajo de los individuos resultaban muy importantes para su promoción, y en teoría todo mundo tenía iguales oportunidades para ganar un puesto de dignidad o de canónigo de oficio, la realidad era muy distinta. Difícilmente se podía esperar un ascenso si no se gozaba de la buena voluntad y opinión de los prelados, a quienes correspondía informar a la Corona sobre las cualidades de sus capitulares y de los posibles candidatos a ascensos. $^{47}$

Candamo, sin duda el más competente de los opositores, debió sentirse de nuevo decepcionado y tal vez indignado ante esta nueva contrariedad, que le recordaría la amarga experiencia de la oposición a la magistralía de la Catedral de Oviedo en 1783-84, que lo decidió a emigrar a Nueva España. ${ }^{48}$ Sin embargo, su esfuerzo no resultó baldío, pues se ganó la confianza del arzobispo Núñez de Haro, muy buen predicador, función específica de la magistralía, lo que permitirá al asturiano en la próxima vacante conseguirla por unanimidad.

43 AGN, Bienes Nacionales, vol. 607, f. 719.

44 González de Candamo, G. 1797-1.

45 ACCM, Actas de las sesiones ordinarias y extraordinarias del Cabildo desde 10 de julio de 1789 hasta el 7 de septiembre de 1792. Libro 57, f. 98v.

46 Aguirre Salvador, R. 2008: 84.

47 Escamilla, I. 1999: 103. Para las votaciones y rivalidades en el cabildo catedralicio de Valladolid de Michoacán, véase Brading, D. 1994 229-232.

48 Astorgano, A. 2014: 12-40.
En 1797 se presentaron otros once clérigos por opositores legítimos a la expresada canonjía, de los cuales tres ya habían participado en la oposición de 1790 (Candamo, Mendívil y Foronda). Fueron los doctores señor don Gaspar González de Candamo; doctor don Feliciano Mendívil, cura de Tegrequiaci; doctor don Pedro Foronda, cura de Santa Ana; doctor don Eusebio Sánchez Pareja, colegial de Santos; doctor don José María Solano, cura de Sesayuca; don Agustín Roxano Mudarra; don Miguel Guridi y Alcozer, cura de Acaxete en el obispado de Puebla; ${ }^{49}$ don José Romualdo Mainar, colegial del Colegio Mayor de Santa María de Todos los Santos (uno de los reformados por el arzobispo Núñez de Haro); don Manuel Burgos, cura de Ystipalapan; don José Guerra, colegial en el Real y más antiguo de San Ildefonso; y don Estanislao Segura, en el del seminario. ${ }^{50}$

Todos estos opositores eran conscientes de que aspiraban a una canonjía rica, y por lo tanto de las más solicitadas, como eran las de las catedrales de México, Puebla y Valladolid de Michoacán.

\section{Oposición a la canonjía magistral de la metropolitana de México (1790)}

En 1790 Candamo volvió a opositar, esta vez a la magistralía de México, y tampoco tuvo éxito. Pero el esfuerzo no resultó inútil, pues atrajo la tención del arzobispo Alfonso Núñez de Haro, quién propuso a Candamo, antes de retornar a Guadalajara, como gobernador eclesiástico de la diócesis de Nuevo León, pues a principio de julio de 1790 acababa de fallecer el obispo Rafael Berger, franciscano amigo de fray Junípero Serra.

El cabildo votó esta canonjía el 3 de septiembre, cuando Candamo ya había sido nombrado gobernador eclesiástico de la diócesis de Nuevo León, el 21 de agosto, según se deduce de la carta del virrey, conde de Revillagigedo, al obispo de Guadalajara, Antonio Alcalde, fechada en México el 27 del mismo mes, en la que le notifica que le mantenga todas las rentas de su canonjía. ${ }^{51}$

En el citado cabildo del 3 de septiembre se procedió a la "votación de la canonjía magistral vacante por ascenso del señor doctor y maestro don José Serruto a la dignidad de tesorero". ${ }^{52}$ Como sabemos le fue adjudicada a Manuel de Omaña, hermano del entonces arcediano de la catedral. En este caso la integración en el grupo de poder adecuado pudo más que el mérito personal de Candamo.

Cuando en 1797 Candamo vuelva a repetir esta oposición a la magistralía, simplemente aduce como méritos los resultados de la votación, sin aludir al contenido de la misma,

49 José Miguel Guridi y Alcocer (San Felipe Ixtacuixtla, Tlaxcala, 23 de diciembre de 1763 - 4 de octubre de 1828), doctorado en Teología en el Colegio Mayor de Santa María de Todos los Santos, será diputado en las Cortes de Cádiz (1810-1812). Cfr. Chust Calero, M. 2009: XXI-LV.

50 ACCM, Año 1797, libro 59, f. 118v.

51 AGN, Provincias Internas, 194, Exp. 4, f. 282. Expediente sobre el gobierno de la mitra del Nuevo Reino de León y expolios del difunto Ilustrísimo D. Fray Rafael Verger.

52 ACCM. Actas de las sesiones ordinarias y extraordinarias del Cabildo desde el 10 de julio de 1789 hasta el 7 de septiembre de 1792 . Libro 57, ff. 97-100v. 
subrayando que en la consulta de 1790 había obtenido "dos votos en primer lugar, cuatro de segundo y dos en tercero". ${ }^{53}$

¿Cómo explicar este fracaso de Candamo? Rodolfo Aguirre resume que "la clerecía del arzobispado de México era numerosa, compleja y sus dirigentes eran herederos de un conjunto de tradiciones y prácticas políticas que trataban de imponer ante cada nuevo arzobispo, con respecto a sus ascensos. La carrera eclesiástica generalmente era larga para quienes la seguían y su éxito dependía de varios factores: las políticas monárquicas y de los arzobispos, la vigencia de modelos de carrera antecedentes y la eficacia de grupos clericales de interés". ${ }^{54} \mathrm{El}$ reformista Candamo había demostrado en reiteradas ocasiones que no tenía miedo a enfrentarse a la tradición. En la Universidad de Salamanca intentó cambiar el escolasticismo en los estudios teológicos. En la catedral de Oviedo no dudó en enfrentarse al obispo González Pisador, que seguía la costumbre de no dejar opositar a los clérigos regulares (y Candamo lo era de la regla de San Agustín en la colegiata de San Isidoro de León) a las canonjías. ${ }^{55}$ La carrera eclesiástica del asturiano se prolongó nueve años más (no tomará posesión de la magistralía de México hasta mayo de 1799) porque en 1790 no había podido integrarse en los grupos clericales dominantes, cosa que conseguirá ese mismo año a través del arzobispo Núñez de Haro, aceptando el difícil empleo de gobernador de la mitra de Monterrey, sede vacante. A sus cuarenta años cumplidos, su carrera estaba estancada en una canonjía de gracia y prefirió no luchar contra la tradición, contra la que había perdido todas las batallas en España y le había casi obligado a emigrar a Nueva España.

\section{La oposición a la canonjía magistral en 1797.}

Perseverante en llegar a la cima de su carrera profesional, a la edad de 45 años Candamo vuelve a opositar a la misma canonjía magistral siete años más tarde, en el transcurso de los cuales se había producido un cambio político importante: el relevo del virrey conde de Revillagigedo por el marqués de Branciforte.

Ambiente político confirmado recientemente por Torres Puga: "No hay duda de que en el cambio de gobierno, de Revillagigedo a Branciforte, la gente cuidó mucho más sus palabras. [...] El gobierno de Branciforte consiguió lo que el virrey de Croix ni siquiera intentó: transmitir el miedo del gobierno a distintos niveles de la sociedad". ${ }^{56}$

Habiendo fallecido el magistral Manuel Omaña (el que había ganado en 1790) el 12 de octubre de 1796, se convoca de nuevo oposición el 25 del mismo mes. El panegirista Miguel Martel resume diciendo que después fue elegido para su canonjía magistral, "mereciendo la mayor confianza de su prelado". ${ }^{57}$ Sin embargo, Candamo no pudo tomar posesión de su canonjía magistral de México, ganada en agosto de 1797, hasta casi dos años después (mayo de

\footnotetext{
53 González de Candamo, G. 1797-1.

54 Aguirre Salvador, R. 2008: 112.

55 Astorgano Abajo, A. 2012-2: 349-397; Astorgano Abajo, A. 2014:

56 Torres Puga, G. 2010: 551.

57 Martel, M. 1805: XXIX.
} 13-112.
1799), por la sencilla razón de que se extravió el expediente en el trasiego entre el Consejo de Indias y el correo de la Nueva España, y fue necesario pedir copia. Esa época de Guadalajara (1787-1799) es la más brillante y más laboriosa de la vida del canónigo asturiano, en nuestra opinión, y no la de México, como sostiene Martel.

En el cabildo del 8 de agosto de 1797, con asistencia del deán Navarro, Conexares (tesorero), Bruno (lectoral), Valencia, y Jarabo (doctoral) y otros canónigos, se anota al margen: "En este cabildo hizo el señor deán la protesta sobre la cédula de la canonjía magistral" (f. 117). El 11 de ese mes se votó dicha canonjía magistral, con un ritual muy similar al ya conocido por la oposición de $1790 .{ }^{58}$ Esta vez, como hemos dicho, Candamo se había presentado contando con el apoyo incondicional de su obispo y ex compañero de Salamanca, Juan Ruiz de Cabañas, y, sobre todo, del anciano arzobispo de México, Alfonso Núñez de Haro, que tantas muestras le había dado de su reconocimiento. Candamo consiguió ganar todos los votos y tomó posesión de su beneficio el 16 de mayo de $1799 .{ }^{59}$ Fueron comisarios, nombrados el 25 de octubre de 1796, los doctores don José de Ruiz de Conexares y don José Mariano Beristáin, quienes mandaron se fijasen los edictos correspondientes. ${ }^{60}$

El Virrey nombró como asistente real que concurriera a dichas oposiciones, con arreglo a la Real Cédula del 16 de junio de 1739, al pro jesuita doctor don Juan Francisco Castañiza, marqués de Castañiza, rector de la Real Universidad y futuro obispo de Durango.

Candamo presentó sus conclusiones el 16 de julio, y el 30 de ese mismo mes realizó la segunda prueba, que consistía en la predicación de un sermón. Esta vez los tres piques se hicieron en los Evangelios y el asturiano eligió el de la Concepción, que es el principio del Evangelio de San Mateo y que comienza: Liber generationis, y acaba: vocatur Christus. Dos días después debía presentarse para decir el sermón, siguiendo el ritual de costumbre. La oposición había terminado para nuestro Candamo.

Una vez cerrado el concurso, el cabildo y el arzobispo admitieron a todos los contrincantes y se citó entonces al pleno del cabildo para el 11 de agosto, día en que se reunieron todos los canónigos, dignidades y el arzobispo en la sala capitular, y se llevó a cabo la votación, en la que "se encontró haber salido en dicho primer lugar con todos los votos el señor doctor don Gaspar González Candamo". ${ }^{61}$

No cabe duda que debió ser uno de los días más felices en la vida de Candamo, quien después de tanta lucha se veía elevado, por fin, a una canonjía de oficio en la catedral más importante de América. El canónigo asturiano contó con el apoyo unánime de todos los que intervinieron en el proceso de oposición, como el observador ("asistente real"), marqués de Castañiza, coopositor de Candamo a la canonjía lectoral en 1789 , rector de la Universidad y futuro obispo de Durango, quien elevó a su superior el virrey, marqués de Branciforte,

\footnotetext{
58 ACCM, Libro 59, ff. 117-119v.

59 Los autos de la oposición están en AGN, Bienes nacionales, vol. 874, ff. 55 y ss.: "Autos de la oposición a la canonjía magistral de la Santa Iglesia Catedral de México al fallecimiento de...".

60 ACCM, Libro 59, f. 117v.

61 ACCM, Libro 59, f. 119.
} 
pariente de Godoy, ${ }^{62}$ el 23 de septiembre de 1797, un informe firmado el 12 de agosto, el día siguiente a la votación. Realmente fue un atento observador que siguió todo el proceso, acudiendo a todo tipo de fuentes de información. ${ }^{63}$

Para Castañiza, Candamo fue indiscutiblemente el mejor, tanto por su literatura mostrada a lo largo de la oposición y en "una carrera muy lustrosa" en Oviedo y Salamanca, como por los servicios prestados a la administración borbónica, "principalmente al gobierno del obispado del Nuevo Reino de León":

"El doctor don Gaspar González Candamo excede, según mi juicio, a todos los demás opositores, así porque se halla ilustrado con una fina literatura superior a la de casi todos los demás, e inferior a ninguno, como por sus méritos ventajosos ciertamente a todos los otros. Él ha hecho en las letras una carrera muy lustrosa, de que ha dado convincentes pruebas en las universidades de Oviedo y de Salamanca y en las iglesias catedrales de Oviedo y de México, igualmente que en la Real iglesia de San Isidro (sic. Isidoro) de León, por los respectivos ejercicios que en todas ha tenido y desempeñado con el lucimiento de un literato distinguido. Sus servicios y méritos contraídos en las iglesias de San Isidro y Guadalajara, y principalmente al gobierno del obispado del Nuevo Reino de León, no son menos recomendables que sus letras, y uno y otro le han granjeado el concepto de un eclesiástico docto y maduro, digno de la mayor recomendación. Por tanto, lo juzgo acreedor al primer lugar de la presente canonjía". ${ }^{64}$

Igualmente favorable, aunque escueto y aséptico, fue el informe del arzobispo de México, Alonso Núñez de Haro y Peralta (1728-1800), al virrey marqués de Branciforte, fechado en México el mismo día de la votación, 11 de agosto de $1797 .{ }^{65}$

Es evidente que, si Candamo ahora consigue la magistralía con el aplauso unánime de todos los agentes sociales que lo habían suspendido en 1789 y 1790 , era porque en el lapso de tiempo (1790-1797) había logrado acumular nuevos méritos, consecuencia de nuevas relaciones formadas en los exámenes para ganar las canonjías anteriores, pero también consecuencia de lazos de amistad con el arzobispo Núñez de Haro, porque la cercanía o lejanía con el arzobispo o con el grupo dirigente del cabildo de turno nos ayuda a explicar nuevos ascensos o estancamientos de las carreras eclesiásticas. ${ }^{66}$ Méritos conseguidos, a pesar de no estar asentado en la capital, donde era más amplio el abanico de posibilidades para relacionarse con los grupos clericales bien instalados y "buscar conveniencias"; es decir, amistades o recomendaciones que le posibilitaran el acceso a un cargo deseado. ${ }^{67}$

Candamo también contó con la complicidad del virrey Branciforte, según el borrador de su oficio al arzobispo y

62 Don Miguel de la Grúa Talamanca de Carini y Branciforte, primer Marqués de Branciforte (Palermo, Sicilia, ca. 1755-Marsella, 1 de junio de 1812) fue un militar español y 52 virrey de la Nueva España. Juzgado por muchos como uno de los virreyes más corruptos de la historia de la colonia, su nombramiento es considerado como el principio del período de decadencia en la historia del virreinato. De la Grúa, casado con una hermana de Godoy, fue enviado a ejercer el gobierno de la Nueva España el 26 de marzo de 1794 y fue removido en 1798, siendo sustituido por Miguel José de Azanza. Cfr. García Puron, M., 1984.

63 AGN, Indiferente Colonial, Caja 2182, Exp. 34, 2v.

64 AGN, Indiferente Colonial, Caja 2182, Exp. 34, 3v.

65 AGN, Indiferente Colonial, Caja 2182, Exp. 34, f. $5 \mathrm{v}$.

66 Aguirre. R. 2004-1: 200.

67 Aguirre. R. 2004-1: 183; Aguirre Salvador, R. 2008: 83-84. cabildo de México, fechado el 17 de agosto de $1797 . .^{68} \mathrm{El}$ nombramiento aún tenía que seguir un largo camino de trámites burocráticos antes de que pudiese tomar posesión de su magistralía. Se cursaban copias al virrey y al arzobispo. Una vez aprobado por ambos, el nombramiento se enviaba al Consejo de Indias, que tenía la última palabra, y daba su consentimiento en nombre del rey.

Hasta abril de 1799 Candamo estuvo en Guadalajara donde desempeñó una agotadora labor como gobernador eclesiástico y hombre de confianza de su amigo el obispo Juan Cruz Ruiz de Cabañas, a pesar de ya presentar algunos problemas de salud relacionados con el hígado (alega algún certificado médico ante el cabildo, aduciendo "cólico biliar"). Uno de los últimos actos que realizó en Guadalajara fue comprar, por 150 pesos, a "doña Gertrudis Trigo, viuda del señor don Estanislao Joaquín de Andino, regente que fue de la Real Audiencia de Quito, vecina de esta ciudad [Guadalajara]", el 29 de marzo de 1799, "un mulato esclavo, nombrado Luis Antonio, color corcho, de edad de veinte y tres años, el cual hubo la señora otorgante por donación que de él le hizo don José Antonio Orcasitas, vecino de la ciudad de Santa Fe, que pasó en ella a los 29 de agosto de 1792, por ante don Pedro Joaquín Maldonado, escribano real, y dicho Orcasitas lo hubo por venta que de él le otorgó don Antonio Nariño a los 14 de febrero de 1787 por ante el mismo escribano". El 10 de abril Candamo paga cuatro pesos y cuatro reales y medio por la alcábala de los 150 pesos. Dado el elevado precio y los antecedentes del esclavo, todo hace suponer que el debilitado magistral compró un culto criado-secretario que lo acompañará el resto de su vida en México. ${ }^{69}$

\section{Actividad del magistral Candamo en el cabildo y en la ciudad de México}

Una vez instalado en la capital de la Nueva España, que desde el siglo Xvı era una urbe inmensa y llena de contrastes, Candamo buscó alojamiento y lo encontró, según la Guía de forasteros de México, en la calle de las Capuchinas (hoy de Venustiano Carranza), muy cerca de la catedral. Se debió sentir muy identificado con Núñez de Haro, quien era hebraísta y hombre de amplia e ilustrada cultura, porque le confió la dirección espiritual del convento que las monjas capuchinas tenían en la Villa de Guadalupe, al que el arzobispo estimaba muy especialmente, tanto que fue su voluntad que en él se enterrara su corazón. ${ }^{70}$

En el arzobispado de México existían varios espacios en donde se tejían día a día las relaciones, se protegían intereses y se consolidaban alianzas, pero el magistral asturiano, con problemas de salud en el hígado, llegaba con el paño de sus pretensiones vitales casi acabado. Es evidente que,

68 AGN, Indiferente Colonial, Caja 2182, Exp. 34, f. 6. Borrador del oficio del virrey Branciforte al arzobispo y cabildo de México, fechado el 17 de agosto de 1797.

69 Archivo Histórico de Instrumentos Públicos de Guadalajara (México), Notario José Tomás de Sandi, tomo IV (año 1799), sin foliar. Así como es raro encontrar escrituras notariales de compraventa de esclavos en España en el siglo XVIII, en México son frecuentes. Así la Hacienda jesuítica de Santa Lucía tenía 291 esclavos en 1722, y 312 en 1743. Cfr. Konrad, H. W. 1995: 277-299.

70 Zayas, G. 1985: 22. 
por fin, don Gaspar había encontrado lo que buscaba: un obispo culto y comprensivo que apreciara sus talentos, un puesto importante dentro de un cabildo prominente y una satisfacción personal y económica por haber llevado a buen término los asuntos que le habían sido encomendados. Su carrera eclesiástica estaba colmada, aunque siempre tendremos la duda de si aspiraba a un obispado, para lo que estaba excelentemente preparado, por haber sido gobernador de las mitras de Monterrey y Guadalajara. En 1800 murió el arzobispo y el magistral fue quien pronunció la Oración fúnebre castellana en sus exequias. ${ }^{71}$ Lógicamente la actividad principal y profesional de Candamo fue la de magistral (predicador oficial), que podemos seguir a través de los libros de actas del Cabildo. ${ }^{72}$

Candamo pasó los cuatro primeros meses de 1799 en Guadalajara en sus cargos de gobernador de la mitra y "juez hacedor de diezmos", pues no toma posesión de la magistralía hasta el 18 de mayo. Desde ese día tiene obligación de asistir a los distintos cabildos, cosa que Gaspar hizo con regularidad, a pesar de sus crecientes achaques hasta el 22 de noviembre de 1803, en que desaparece de los libros de actas del Cabildo, ${ }^{73}$ según se puede apreciar en la siguiente tabla:

LA PARTICIPACIÓN DE CANDAMO EN EL CABILDO DE MÉXICO: en negrita las asistencias; en cursiva las ausencias.

\begin{tabular}{|c|c|c|c|c|c|c|}
\hline Meses & 1799 & 1800 & 1801 & 1802 & 1803 & 1804 \\
\hline Enero & & $\begin{array}{l}7,9,11,13,18 \\
10,14,21,29 \\
30\end{array}$ & $\begin{array}{l}9,10,13,12, \\
16,21,22,24, \\
29\end{array}$ & $\begin{array}{l}8,9,22,28,29 \\
12\end{array}$ & $\begin{array}{l}7,8,10 \text { (dos } \\
\text { cabildos), 12, 13, } \\
15,21,28,18\end{array}$ & $\begin{array}{l}7,9,11,16,21 \\
27\end{array}$ \\
\hline Febrero & & $21,4,7,11,27$ & $\begin{array}{l}4,7,10,11,13 \\
14,19,27\end{array}$ & $\begin{array}{l}1,9,12,16,19 \\
23,26\end{array}$ & 4,11 & $4,7,10,16,28$ \\
\hline Marzo & & $15,4,20,27$ & $\begin{array}{l}31,1,3,4,10 \\
17,20,27\end{array}$ & 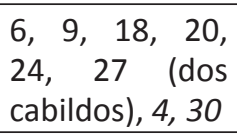 & $\begin{array}{l}3,8,15,24,1 \text {, } \\
29\end{array}$ & $1,3,4,6,20,17$ \\
\hline Abril & & $\begin{array}{l}14,1,8,18,22 \\
25,29,30\end{array}$ & $\begin{array}{l}14,17,21,24, \\
1,8,18,22,27, \\
28,30\end{array}$ & $\begin{array}{l}6,8,13,27,30 \\
1,3,8\end{array}$ & $\begin{array}{l}5 \text { (dos cabildos), } \\
19,22,26,27, \\
28,10,29\end{array}$ & $\begin{array}{l}7,10,13,15, \\
17,20,24,27, \\
29\end{array}$ \\
\hline Mayo & 18,21 & $\begin{array}{l}6,9,13,20,23 \\
26,29,31\end{array}$ & $\begin{array}{l}18,22,9,13 \\
19,20,23,26, \\
29,31\end{array}$ & $\begin{array}{l}4,5,6,12 \text { (dos } \\
\text { cabildos), } 16, \\
29,7,14,22\end{array}$ & $4,5,6,10,13$ & $\begin{array}{l}\text { 4. En el acta del } \\
11 \text { se anota que } \\
\text { falleció el } 16 \text { y } \\
\text { fue enterrado } \\
\text { el } 18 \text {. }\end{array}$ \\
\hline Junio & $1,7,21,25$ & $9,4,6,16,21$ & $\begin{array}{l}9,16,19,23 \\
26,30,4,6,10 \\
12,16,21\end{array}$ & $\begin{array}{l}1,11,30,4,21 \\
22\end{array}$ & 3,27 & \\
\hline Julio & $\begin{array}{l}5,9,12,23,27, \\
30\end{array}$ & $\begin{array}{l}11,19,1,4,8 \\
15,26,29\end{array}$ & $\begin{array}{l}3,10,11,13 \\
14,17,18,28 \\
31,1,4,8,15 \\
21,24,26,29\end{array}$ & $\begin{array}{l}3,4,6,9,13 \\
15,17,20,23 \\
30,24\end{array}$ & $19,21,8,15$ & \\
\hline Agosto & $8,12,20$ & $1,5,8,22$ & $\begin{array}{l}5,12,29,1,5 \\
7,8,12,21,22\end{array}$ & $\begin{array}{l}3,5,9,17,20 \\
14,26\end{array}$ & $\begin{array}{l}2,9,12,19,20 \\
5,26,27\end{array}$ & \\
\hline Septiembre & $\begin{array}{l}6,19,20,27 \\
14,25\end{array}$ & $\begin{array}{l}2,6,12,16,19 \\
23\end{array}$ & $11,22,18,25$ & $\begin{array}{l}4,7,10,18,22 \\
24,25\end{array}$ & $\begin{array}{l}3,6,13,16,17 \\
20,23,26,25\end{array}$ & \\
\hline Octubre & $\begin{array}{l}11,19,6,8,22 \\
25,31\end{array}$ & $\begin{array}{l}10,13,21,24, \\
31\end{array}$ & $\begin{array}{l}20,23,30,3,6, \\
27\end{array}$ & $\begin{array}{l}8,1,5,13,26, \\
9,11,19\end{array}$ & $\begin{array}{l}1,6,7,11,19 \\
21,25,31\end{array}$ & \\
\hline Noviembre & $28,8,15,19,29$ & $\begin{array}{l}14,18,7,11 \\
25,28\end{array}$ & $\begin{array}{l}6,14,18,20 \\
24,27\end{array}$ & $\begin{array}{l}5,10,19,24, \\
16,27\end{array}$ & $8,15,22,5$ & \\
\hline Diciembre & $3,10,14,24,27$ & $3,19,13,16,22$ & $\begin{array}{l}2,4,10,14,19 \\
30,27\end{array}$ & $\begin{array}{l}2,4,7,14,17, \\
20,23,27,30, \\
10,16\end{array}$ & $\begin{array}{l}7,10,16,20 \\
23,24,30\end{array}$ & \\
\hline
\end{tabular}

72 ACCM, Libros 59 al 62. ACCM, libro 59. Actas de las sesiones ordinarias y extraordinarias del Cabildo desde el 20 de mayo de 1796 al 27 de diciembre de 1799, fojas 354, con índices; ACCM, Libro 62, Actas de las sesiones ordinarias y extraordinarias del Cabildo desde el 7 de diciembre de 1804 hasta el 31 de diciembre de 1806.

${ }_{73}$ ACCM, Actas de las sesiones ordinarias y extraordinarias del

71 González de Candamo, G. 1801: I-XLVIII. Cabildo. Libros 59-61. 
Para comprender esta tabla hay que tener en cuenta que Candamo, en muchas asistencias al cabildo, lo abandonaba pronto para atender sus obligaciones litúrgicas y pastorales, bajo expresiones como "al coro" o "al altar", delegando su voto en algún canónigo amigo, como los señores Madrid o Mier. Es decir, en el crepúsculo de su vida, el enfermo y cansado magistral se desentendía bastante de las cuestiones burocráticas y administrativas del Cabildo.

La vida de Candamo dentro del Cabildo, a veces presidido por el arcediano Villaurrutia, fue de lo más rutinario durante cuatro años y medio (desde mayo de 1799 hasta noviembre de 1803), sin encargarse de comisiones complicadas. No vamos a enumerar las ausencias de Candamo, que siempre fueron más numerosas que las asistencias, como puede apreciarse en la tabla de participación anterior.

Las pocas veces que tomó la palabra fueron para exigir honradez en la recaudación de los diezmos, que era una fuente de conflictos, porque los administradores solían apropiarse fraudulentamente de cierta cantidad de los mismos. Candamo estaba sensibilizado con esta cuestión, pues, durante su gobernación del obispado del Nuevo Reino de León (actual Monterrey), se vio implicado en el largo pleito que el anterior gobernador eclesiástico (1780-1783), el canónigo Bustamante, había ocasionado por haberse apropiado de más de 150.000 pesos fuertes.

Candamo prefecto de la Congregación de la Real Congregación de los Naturales y originarios del Principado de Asturias y Obispado de Oviedo (1799).

Una vez conseguida una cierta estabilidad económica (ya que como canónigo de oficio de la catedral metropolitana de México ganaba ocho mil pesos fuertes anuales, más otros ingresos, como la dirección espiritual de las monjas capuchinas), Candamo mandó llamar a su hermano menor Nicolás Antonio (conocido como "el cura del Atenco"), clérigo de órdenes menores, el cual recibirá en propiedad una capellanía, cuyos beneficios le reportarán tres mil pesos. Nicolás se comprometió a oficiar cincuenta misas en favor de su benefactor, cuando recibiera la ordenación. ${ }^{74}$

También nos consta la vinculación de Gaspar con los asturianos de México, pues a los pocos meses de tomar posesión de su magistralía, el 17 de septiembre de 1799 fue nombrado "prefecto» de la Real Congregación de los Naturales y originarios del Principado de Asturias y Obispado de Oviedo, según la noticia correspondiente publicada en la Gazeta de México:

"El día diez se celebró, en la Iglesia de Santo Domingo, la fiesta de Nuestra Señora de Covadonga por su llustre y Real Congregación de los Naturales y originarios del Principado de Asturias y Obispado de Oviedo, con la solemnidad y grandeza que acostumbra, siendo el Orador el Señor Dr. Don Joseph Mariano Beristáin, Canónigo de esta Santa Iglesia Metropolitana, que desempeñó el Sermón a satisfacción del respetable concurso, y el día 17 se procedió a la

74 AGN, Bienes Nacionales, Vol. 1006, Exp. 20, “Colación que tomó don Nicolás Antonio González de Candamo de una de las dos capellanías que mandó fundar don Jacinto Martínez y Aguirre". elección de oficios, obteniendo el de Prefecto el Señor Dr. D. Gaspar González de Candamo, Canónigo Magistral de la referida Santa Iglesia; [...] y concluida la elección pasaron al cumplimiento de estilo a los palacios de los Exmos. Señores Virrey y Arzobispo". ${ }^{75}$

Obsérvese la presencia del canónigo y excelente bibliógrafo Mariano Beristáin, amigo de Candamo y próximo a los asturianos, quienes le solicitaron el sermón con motivo de la celebración de Nuestra Señora de Covadonga de $1799 .{ }^{76}$

La figura de Candamo iba tomando presencia en la vida social de la capital mexicana. Como sabemos, al año siguiente se vio implicado de lleno en las exequias fúnebres del arzobispo Núñez de Haro, en las que la ciudadanía de México se esmeró de una manera especial para honrar a quien había sido virrey unos meses y su pastor espiritual durante casi treinta años.

\section{EL SOCORRO ENVIADO POR CANDAMO AL INSTITUTO ASTURIANO DE GIJÓN (1804) 77}

Sin duda Candamo seguía con atención la aventura pedagógica de su amigo Jovellanos en Gijón, quien, en 1791, propone la creación en dicha ciudad de una Escuela de Mineralogía y Náutica, para instruir personas capaces de explotar una mina o de pilotar un barco con una buena preparación académica y profesional. Ambos asturianos propugnaban que la instrucción es la base del progreso económico, y el Instituto podría aumentar, con una enseñanza moderna, la riqueza de Asturias y el bienestar de sus gentes. Idea sistemáticamente defendida por Candamo, junto con Meléndez Valdés, en el claustro de la Universidad de Salamanca.

Alcanzado el desahogo económico en 1799 (unos 8000 pesos al año), Candamo debió ahorrar lo suficiente como para beneficiar a su familia e intentar devolverle los favores a sus amigos, en concreto, envió 2300 pesos en 1804, pocos meses antes de fallecer «inesperadamente», para socorrer al Instituto Asturiano. Cantidad de cierta importancia (casi la tercera parte del salario de su magistralía en un año), que, al parecer, no llegó a su destino. Además, hubiese llegado en el momento más oportuno, pues, tanto el Instituto, como su fundador Jovellanos, pasaban por malos momentos. El 15 de agosto de 1798 - tras un intento de envenenamiento, según Caso González - Jovellanos es cesado como ministro de Gracia y Justicia, y en la primavera de 1801 es desterrado a Mallorca, por lo que aumentan las dificultades del Instituto Asturiano y su Escuela Náutica, que estaba construyendo un nuevo edificio, el cual había sido comenzado el 19 de octubre de 1797, pasando a ser ocupado en julio de 1804, y finalizándose las obras algún año después, en 1807. En este contexto hay que comprender la oportuna ayuda económica que Candamo envía desde México en $1804 .{ }^{78}$ La mala suerte acompañó a Candamo hasta después de su

\footnotetext{
75 Manuel Antonio Valdés, M. A. 1799. Gazeta de México 10-4, t. X: 26. México: Imprenta de Don Mariano Zúñiga y Ontiveros.

76 Véase un reciente perfil biográfico de Beristáin en Torales Pacheco, Ma C. 2010: 444-462.

77 Estudiado con más amplitud en Astorgano, A. 2011-2.

78 Cfr. Astorgano, A. 1999: 995-1052.
} 
muerte, según deducimos de un expediente conservado en el AGN de México, ${ }^{79}$ que resumimos. El 4 de marzo de 1808 el ministro de Marina, Francisco Gil de Taboada, ${ }^{80}$ le escribe desde Aranjuez a Iturrigaray, ${ }^{81}$ virrey de México, exponiéndole que, después de cuatro años, no habían llegado al Instituto los citados 2300 pesos que Candamo había enviado poco antes de morir. ${ }^{82}$

Desterrado Jovellanos, Francisco Gil, en su calidad de Director General de la Armada, asumió la tutela del Instituto y pone en conocimiento de Godoy los antecedentes del caso el 5 de febrero de 1808:

"Serenísimo Señor [Godoy]: desde la época en que se estableció en la villa de Gijón el Instituto Asturiano, dirigió su protector [Jovellanos] circulares a los dominios de Indias, alentando a los naturales del Principado de Asturias, residentes allí, a que, por un efecto de patriotismo, franqueasen la cantidad que tuvieren a bien para plantear el Instituto y ponerle sobre el pie a que entonces se encaminaban las ideas. Nombró al mismo tiempo algunas personas de probidad y carácter que se encargasen de los recaudos y remisión a Europa del dinero que recibiesen, las cuales, al parecer, se encomendaron de ello por el mismo principio de patriótica generosidad que condujo después a sus paisanos a las dádivas voluntarias. Cambiado posteriormente este sistema, reducido el Instituto a Escuela Náutica y encargado yo [Francisco Gil] por Real Orden, como Director General de la Armada, de su establecimiento y posteridad, pedí en abril de 1804 noticia del estado de todos los fondos con que se hallaba y contaba el Instituto". ${ }^{83}$

Todos los esfuerzos del director del Instituto Asturiano, José Cienfuegos, habían resultado inútiles para cobrar el legado de Candamo. ${ }^{84}$ Ante la nula colaboración de los albaceas del testamento de Candamo, en especial su hermano Nicolás, el virrey Iturrigaray interviene ante el cabildo de la Metropolitana de México para que reservase esa cantidad a la hora de liquidar la testamentaría del magistral. En estas gestiones se habían empleado más de cuatro años (1804-1808), por lo que a principios de 1808, el ministro de Marina, Francisco Gil de Taboada, decide activar el cobro de los 2300 pesos, implicando al mismo Manuel Godoy, quien, a finales de febrero de 1808, autoriza que se ejecute el cobro a favor de la Real Escuela Náutica de Gijón, pues "es incontestable que la testamentaría del magistral es deudora

\footnotetext{
79 AGN, Indiferente Virreinal, caja 6132, Exp. 1, ff. 37-40.

80 Francisco Gil de Taboada Lemos y Villamarín (Santa María de Soto Longo, 1736 - Madrid, 1809) fue un noble, político, militar y marino español, IX virrey de Nueva Granada (1789), 32. o virrey del Perú (17901796) y XIo capitán general de la Real Armada Española. En 1799 fue nombrado Director General de la Armada, primero con carácter interino y después en propiedad. Por Real Decreto del 22 de abril de 1806, se le nombró ministro de Marina, en propiedad. También siguió desempeñando la Dirección General de la Armada hasta 1807, en que se dispuso que, en sustitución de dicho cargo, se crease el empleo de inspector general de Marina. Ejerciendo todos estos altos cargos sobrevino el Motín de Aranjuez y los graves sucesos que le siguieron, entre ellos la abdicación del rey Carlos IV en su hijo Fernando VII.

81 José Joaquín Vicente de Iturrigaray y Aróstegui (Cádiz, 1742 - † Madrid, 1815) fue virrey de Nueva España desde 1803 hasta 1808.

82 AGN, Indiferente Virreinal, caja 6132, Exp. 1, ff. 37-40.

83 AGN, Indiferente Virreinal, caja 6132, Exp. 1, ff. 37-40.

84 AGN, Indiferente Virreinal, caja 6132, Exp. 1, ff. 37-40. Sobre los barcos españoles de estos años puede leerse el libro de Vicente Ruiz García (2013).
}

a este establecimiento [Real Escuela Náutica] de los 2300 pesos fuertes que vuestra excelencia [el virrey Iturriagaray] mandó retener en la clavería de esa catedral. Ruego a vuestra excelencia se sirva providenciar lo conveniente para que, en ocasión segura y oportuna, se remita dicha suma al director de la citada Real Escuela, para que se la dé la aplicación que competa en beneficio del mismo establecimiento". 85

Sospechamos que el Instituto Asturiano no pudo beneficiarse del socorro del magistral, principalmente, por la desidia o malicia de su hermano Nicolás Candamo, quien, en definitiva, fue el único heredero, según conjeturaba en 1808 el ministro de Marina, Francisco Gil de Taboada: «el cura del Atenco, uno o acaso él solo heredero del magistral». ${ }^{86}$

\section{LA PRODUCCIÓN LITERARIA DE CANDAMO: El PANEGÍRICO DEL ARZOBISPO NÚÑEZ DE HARO (1800)}

El contenido del conjunto denominado genéricamente como "sermones" puede considerarse como una vertiente literaria que caracterizó al Siglo de Oro y al Barroco. Fue una actividad que se dio como parte de la reforma cristiana, a través de la difusión de la doctrina católica, cuyas "funciones tradicionales [...] eran catequizar y moralizar". ${ }^{87}$

Los sermones novohispanos representan un importante grupo de impresos que comenzaron a producirse desde el siglo XVI. Se calcula que se imprimieron poco más de 2000, pero el repertorio bibliográfico de José Toribio Medina indica una cifra de alrededor de $1812 .{ }^{88}$ Por su parte Perla Chinchilla dice que se editaron entre los años 1600 y 1700 , un total de 468 sermones en una producción total de 1776 impresos. ${ }^{89}$

Estos sermones conforman un grupo de impresos que ha sido escasamente trabajado por especialistas, puesto que son considerados como un "fárrago impertinente o material encubridor", ${ }^{90}$ en comparación con el interés que ha despertado el sermón en la producción literaria del Siglo de Oro español. ${ }^{91}$ Esta ausencia de importancia también incluye la falta de interés en su materialidad (mal papel y encuadernación), por lo que pueden ser considerados como impresos menores, muy expuestos a su pérdida y destrucción, identificados como "folletos", y como tales catalogados y clasificados en las bibliotecas contemporáneas. ${ }^{92}$

Actualmente sabemos que en estos impresos "tampoco la extensión era unánime, y que el sermón publicado era ciertamente más largo que el predicado", ${ }^{93}$ sobre todo cuando observamos los preliminares de cada impreso, pues

85 Según consta en el certificado de defunción, AGN, Clero regular y secular, vol. 208, ff. 283-286, f. 285.

86 AGN, Indiferente Virreinal, caja 6132, Exp. 1, ff. 38v.

87 Cerdán, F. 2002: 23; García Aguilar, I. 2009: 259.

88 Las fuentes principales para conocer los sermones impresos en México son dos: la Biblioteca hispanoamericana septentrional de Beristáin (1816-1821) y La imprenta en México, 1539-1821, de J. T. Medina (1908-1912, 8 vols.).

89 Chinchilla, P. 2004: 43.

90 Herrejón, C. 2003: 61.

91 Cerdán, F. 2002: 9-42.

92 García Aguilar, I. 2009: 228-229.

93 Chinchilla, P. 2004: 56. 
en algunos de ellos llegaron a "igualar y aún a superar el número de páginas del sermón". ${ }^{94}$ En los sermones de Candamo la menor extensión está en el sermón moral de la monja Sánchez-Leñero (32 pp.), mientras que el panegírico de Carlos III tiene 46 y el del arzobispo Núñez de Haro 48 páginas en números romanos, porque se imprimió dentro de la amplia (162 pp.) Relación de la fúnebre ceremonia y exequias que narra lo sucedido en torno a la muerte del personaje, redactada por el jesuita expulso retornado Juan Luis Maneiro (1744-1802). ${ }^{95}$

Sin duda, los sermones representan una transición de la cultura oral de la predicación (como fenómeno de espacio social), hacia la transformación en una cultura impresa (como un espacio privado)..${ }^{96}$ Cuando el magistral Candamo (predicador de oficio) peroraba en las catedrales de Guadalajara o México, la figura del predicador era importante por el empleo de diferentes elementos casi teatrales (como la gesticulación) para transmitir fervor sobre las cosas divinas y enmarcarlas en el espacio del templo, que en el caso del funeral del arzobispo Núñez de Haro era un monumental conjunto escultórico ("Pira o Máquina sepulcral”, lo califica Juan Luis Maneiro, autor de la Relación), ideado por Manuel Tolsá, y así conseguir el adoctrinamiento social, no sólo de corte religioso sino también político. Candamo, que había conseguido la canonjía magistral de la Colegiata de San Isidoro de León a los veinte años (1773) era el orador sagrado experimentado ideal para tales solemnidades.

Candamo, antiguo catedrático de Hebreo y opositor a la Cátedra de Sagrada Escritura de la Universidad de Salamanca, prepara concienzudamente sus sermones, a juzgar por las abundantes y precisas citas que autorizan su pensamiento. Dice Herrejón Peredo que el predicador religioso casi nunca fracasaba, aunque no persuadiese a sus oyentes, que daban el visto bueno a su misión. ${ }^{97}$ Pero el canónigo asturiano nos ha dejado unos sermones bien preparados, persuasivos y alejados del retorcimiento de la retórica barroca a la que odiaba en todos los ramos literarios. En los respectivos currícula no se olvida de anotar los sermones más notables, como los que dijo en Madrid ante el Consejo de Castilla en 1785. Si lo hemos visto hacer todo tipo de méritos hasta alcanzar la magistralía de México, lógico es pensar que en una época en la que los hombres del clero valoraban cada vez más la impresión de sus discursos, ${ }^{98}$ Candamo se sirviese de ellos en su promoción personal para obtener ascensos en la carrera eclesiástica; y el panegírico de Núñez de Haro (1800), sería uno de los últimos escalones para llegar al obispado, como sugiere Beristáin.

Candamo no forma parte de la escuela poética salmantina, de la que su amigo Meléndez Valdés era el líder, como demuestra el hecho de que no se le conozca ningún nombre poético ni ningún escrito en prosa de cierta entidad redactado en España. Sin embargo, fue un orador sagrado de primera fila, como se puede observar al leer los tres únicos

\footnotetext{
94 Herrejón, C. 2002: 433.

95 Maneiro, J. L. 1801.

96 García Aguilar, I. 2009: 229.

97 Herrejón, C. 2003: 10.

98 Chinchilla, P. 2004: 37.
}

discursos conservados y escritos en Nueva España, que sólo podemos analizar someramente ahora. ${ }^{99}$ Candamo, canónigo magistral y orador sagrado, lógicamente, se especializó en sermones, a juzgar por los que imprimió. Son dos panegíricos (en honor a Carlos III y al arzobispo Núñez de Haro) y un sermón moral dirigido a una monja de Guadalajara que acaba de profesar.

El magistral asturiano cultiva dignamente el género retórico del panegírico, tan difundido en el siglo XVIII que algunos tratadistas deseaban restringirlo a los personajes notables. Es el panegírico uno de los discursos retóricos más dificultosos, porque como su asunto, por lo común, deba ser heroico y sublime, es necesario expresarlo con todo aquel aparato de elocuencia, artificio de sentencias, pruebas y estructura que convenzan la heroicidad del sujeto. ${ }^{100}$

Los dos panegíricos fueron predicados en sendas catedrales, pero el de Carlos III en la de Guadalajara (1789) resulta mucho más atractivo que el del arzobispo Núñez de Haro en la de México (1800). La razón quizá esté en que el primero es casi un panegírico profano y el segundo "más evangélico y erudito". En efecto, el elogio de Carlos III es una fluida narración de hechos, presentada con el fervor reformista de un ilustrado que era consciente del momento histórico que estaba viviendo, mientras que el panegírico del arzobispo Núñez de Haro está más sujeto al corsé de la oratoria sagrada y su erudición. ${ }^{101}$

El discurso dirigido a la monja de Guadalajara pertenece a otra clase de sermones, los morales, y por tanto tiene otras características, que hemos analizado en otra parte. ${ }^{102}$ Es un sermón que tiene un lado negativo (los problemas y las dudas que se le plantearán a la monja dominica sobre su vocación), a pesar de la alegría festiva del acto. Pero el canónigo asturiano no es un moralista que se dedica a ir amargando la vida a la gente, sino que actúa como un buen médico de almas ${ }^{103}$ (no debía de ser mal sicólogo) sobre una materia (la vocación religiosa) que conocía por larga experiencia. Considera a su monja como una posible enferma y reflexiona sobre el origen y raíz de donde le pueden venir los problemas a su vocación (la malicia ajena o la ignorancia culpable propia) para mantener la perseverancia, lo cual, necesariamente, requerirá sacrificios.

La crónica de la muerte del arzobispo Núñez de Haro, protector de Candamo. ${ }^{104}$

En 1800 murió el arzobispo de México Núñez de Haro, protector de Candamo desde que opositó por primera vez (1789) a la canonjía lectoral de la Metropolitana. A él debió el

99 González de Candamo, G. 1789; González de Candamo, G. 17972; González de Candamo, G. 1801. Para un análisis más detallado del mejor de los tres discursos, el panegírico de Carlos III, cfr. Astorgano, A. 2013-1.

100 Obregón, 1784: 8-9.

101 Connaughton, B. 1987: 159-188.

102 Astorgano, A. 2013-1.

103 Esta alegoría la volverá a desarrollar en el panegírico del arzobispo Núñez de Haro. Candamo, 1801: XVIII-XXVII.

104 Una magnífica síntesis de todo el proceso es narrado por el cronista oficial del mismo, el jesuita retornado Juan Luis Maneiro (1801). 
asturiano la gobernación del obispado de Monterey (17901792). El magistral asturiano fue quien pronunció la oración fúnebre castellana en sus exequias, tanto por amistad como por razón de su oficio. Es una pieza oratoria en la que se deja sentir fuertemente el amor y la admiración que Candamo profesaba a su arzobispo. Quizá, por esa misma razón, éste es el menos interesante de los tres sermones que conocemos. Está escrito en un tono emotivo y es un panegírico de las virtudes de quien, por otra parte, fue un virrey criticado por los criollos. En suma, se trata de una obra convencional y farragosa, aunque no de mala factura. ${ }^{105}$

En el cabildo del 9 de mayo de 1800, con asistencia del magistral Candamo, se notifica la gravedad de la enfermedad del arzobispo Núñez de Haro, mediante una carta del día anterior de su secretario particular y futuro biógrafo, Manuel de Flores, dirigida al deán Valentín García Narro, ${ }^{106}$ en la que solicitaba que se hiciesen rogativas por la salud del arzobispo. ${ }^{107}$

El cabildo acordó hacer un novenario por el señor arzobispo, celebrándose en el altar mayor a nuestra Señora de la Asunción y a nuestro señor San José. ${ }^{108}$ A continuación se leyó la Real Cédula, fechada en San Lorenzo el 30 de octubre de 1799 , sobre que se hagan honores fúnebres a su santidad el papa Pío VI, recientemente fallecido. ${ }^{109}$

En el cabildo del 13 de mayo de 1800 se acordó la "asignación del día 27 [de mayo de 1800] para las honras del papa y el 28 para la misa pro eligendo Sumo Pontífice". Era práctica que el arzobispo hiciese el convite de asistencia al virrey, a la Real Audiencia y a la Ciudad, como se había hecho el 28 de julio de 1769, 1ㅇde agosto y 3 de agosto de 1769 a la muerte del papa Clemente XIII. ${ }^{110}$

En el cabildo del 26 de mayo de 1800 se tiene noticia del fallecimiento del arzobispo Núñez de Haro, y respecto a las honras fúnebres "se acordó que todo se verifique con la magnificencia debida a las recomendables circunstancias del Excmo. Sr. difunto, arreglándose en lo que convenga al Manual que se formó, de orden de éste venerable cabildo, cuando falleció el Ilmo. Sr. Rubio [Salinas]". ${ }^{111}$

Asimismo se acordó que mientras tanto se declara la sede vacante, resida en el señor deán la jurisdicción para determinar lo que fuere necesario y no admitía demora, tanto en lo contencioso cuanto en lo gubernativo. Antes de concluirse esta junta llegó el canónigo Gamboa y dio cuenta de haber pasado, en compañía del tesorero Conexares, a participar al virrey el fallecimiento del prelado; y que habían convenido con él que se nombrase un comisionado, "que

\footnotetext{
105 Zayas, G. 1985: 23.

106 ACCM, Libro 60, ff. 31-31v. Actas de las sesiones ordinarias y extraordinarias del Cabildo desde 7 de enero de 1800 hasta el 4 de septiembre de 1802

107 ACCM, Libro 60, ff. 31-32.

108 ACCM, Libro 60, ff. 31-32.

109 ACCM, Libro 60, f. 32.

110 ACCM, Libro 60, f. 32v.

111 ACCM, Libro 60, f. 36. Manuel José Rubio y Salinas, canónigo de la regla de San Agustín, como González de Candamo, fue arzobispo de México entre el 29 de enero de 1748 y el 3 de julio de 1765, en que falleció. En efecto fue el último al que se le hicieron honras fúnebres, pues su sucesor Francisco Antonio de Lorenzana y Butrón fue trasladado a Toledo el 27 de enero de 1771.
}

acordase con su excelencia familiarmente todo lo que convenga en cuanto a las disposiciones del entierro y honras que deben hacerse al excelentísimo señor difunto". Se determinó que desempeñe dicha comisión el mismo Gamboa. ${ }^{112}$

El Sermón de las honras del difunto arzobispo, pronunciado por Candamo, es uno de los muchos actos que tuvieron lugar con motivo del fallecimiento de un personaje importantísimo en la Nueva España, ya que, además de arzobispo durante casi 28 años, fue virrey durante tres meses y medio (desde el 8 de mayo hasta el 16 de agosto de 1787), precisamente cuando el canónigo asturiano aterrizaba en México. Es la pieza más interesante de la Relación de la fúnebre ceremonia y exequias que narra lo sucedido en torno a la muerte del personaje, ${ }^{113}$ que va precedida de una dedicatoria al arcediano y cabildo de la Iglesia Metropolitana de México. El opúsculo de Candamo ocupa 48 páginas de un total de 162. En los preliminares de la Relación tenemos los siguientes componentes: 1. Parecer del Dr. fray Ramón Casaus, de la sagrada Orden de Predicadores, catedrático del doctor Angélico en la Real y Pontificia Universidad de México, y examinador sinodal del arzobispado, 21 de septiembre de 1801. 2. Dictamen del Maestro Dr. fray Ángel Casao, provincial de su Provincia del dulcísimo nombre de Jesús, de la Orden de N. G. P. San Agustín en esta la Nueva España, 20 de noviembre de 1801. 3. Licencia del superior gobierno, dada por el virrey don Félix Berenguer de Marquina, el 22 de septiembre de 1801. 4. Licencia del presidente y cabildo sede vacante, por los canónigos M. de Valencia, Sarriá, Foncerrada y Gómez, fechada el 24 de noviembre de 1801.

El anónimo cronista, "un presbítero de este arzobispado", 114 empieza su Relación elogiando al extinto arzobispo por su sabiduría y amplia cultura, que adquirió durante sus estancias en Bolonia, Roma, Segovia y Toledo, la cual derramó en la Nueva España durante 28 años. Las bases de su gobierno fueron una insigne mansedumbre, una bien manejada concordia, una liberalidad casi sin límites y una urbanidad a toda prueba. Los adornos de su alma fueron la humildad, la misericordia, la prudencia y la fortaleza, entre otros. Destaca las obras de beneficencia que llevó a cabo el arzobispo Núñez de Haro: el Convento de Capuchinas, "levantado en la dura roca del Tepeyac", el colegio de San Miguel de Belén, el Hospital General para enfermos desamparados, la Casa de retiro para la oración y silencio de los eclesiásticos descarriados. Fue un virrey arzobispo que, guiado por la sabiduría, manejó con acierto y prudencia tanto el bastón como el báculo pastoral, "sin embarazarse ni confundirse en el caos inmenso de negocios, que debe presentar la unión de ambas potestades" (obispo y virrey).

A continuación Maneiro se refiere a la larga enfermedad que postró al arzobispo hasta que llegó el fin de su

112 ACCM, Libro 60, f. 36.

113 Maneiro, J. L. 1801. La Relación de la fúnebre ceremonia está estructurada en cuatro partes, cuya extensión es de 8, 80, 26 y 48 páginas. El sermón de Candamo es el más amplio (pp. I-XLVIII).

114 Hoy sabemos que el autor de la Relación es el ex jesuita Juan Luis Maneiro, autor de una treintena de biografías de jesuitas mexicanos fallecidos en el exilio italiano, y uno de los cinco que consiguieron retornar a Nueva España, aprovechando el permiso concedido por Godoy en 1798. Saint Clair Segurado, E. Mạ. 2005: 368-371. 
existencia, el 26 mayo 1800. Pero antes de esto, el 20 de mayo, se determinó que le fuera administrado el sagrado viático por el deán, Valentín García Narro. Fueron nombrados como asistentes del enfermo, para auxiliarlo hasta el último instante de su vida, los miembros del cabildo eclesiástico, el doctor José Ruiz de Conexares, dignidad tesorero (poco después maestrescuela), y el licenciado y maestro Juan Antonio Bruno, canónigo lectoral. Para auxiliar a estos, y a petición del enfermo, fueron nombrados el rector del Real Colegio de Tepotzotlán, bachiller don Cristóbal Mendoza, el padre Manuel Bolea, prepósito que fue de la Congregación de San Felipe Neri, y el padre Juan Solís, prefecto de San Camilo. El 25 de mayo, Núñez de Haro pidió que se le administrara el sacramento de la Extremaunción, lo que le fue ejecutado por el cura más antiguo de la catedral, el licenciado Juan Francisco Domínguez. Los comisionados que se hicieron cargo de las funciones lúgubres fueron Ruiz de Conexares y Bruno, los canónigos que habían asistido en los últimos días de su enfermedad al arzobispo. Seguidamente el anónimo memorialista (Maneiro) describe la procesión, el funeral y la ceremonia en la iglesia, cuya misa cantada estuvo a cargo del maestrescuela (poco después arcediano) doctor Juan Francisco Campos, ayudando como diácono el prebendado doctor Ciro de Villaurrutia, y como subdiácono el prebendado licenciado Francisco Ignacio Gómez de Pedroso. EI relato de los hechos viene a coincidir con la noticia aparecida en la Gazeta de México del miércoles, 18 de junio de $1800 .{ }^{115}$

Respecto a las honras fúnebres, propiamente dichas, que se celebraron en noviembre, el anónimo presbítero también las reseña. El encargado de predicar la oración latina fue el prebendado doctor y maestro José María del Barrio y la oración en castellano fue dicha por el canónigo magistral doctor don Gaspar González de Candamo. Oficiaron misa, de preste el arcediano doctor Juan Francisco Campos, de diácono el prebendado (poco después canónigo) doctor don Juan de Sarriá, y de subdiácono el prebendado licenciado Ignacio Picó. Los cinco responsos acostumbrados fueron cantados por Juan Francisco Campos, por el inquisidor canónigo (poco después dignidad tesorero) Juan de Mier y Villar, por el canónigo lectoral Juan Antonio Bruno y por el canónigo Dr. Pedro García de Valencia y Vasco. A continuación describe el mausoleo, cuyo autor fue el arquitecto Manuel Tolsá, director de la Academia de Bellas Artes de México, así como los adornos y las estatuas representando las principales virtudes del difunto: mansedumbre, concordia, liberalidad y urbanidad. Seguidamente presenta las poesías colocadas en la pira con una explicación de su significado.

Por último, reproduce las dos "oraciones", es decir, sermones panegíricos. La primera, en latín: Panegyrica oratio in solemnibus exequiis excellentissimi ac Illustrissimi viri Ildefonsi Nugnetii de Haro et Peralta, mexicanorum Pontificis olimque pro-regis maximo civitatis istius templo. A Josepho Maria del Barrio, pronuntiata IX kalendas Decembris. Ann. CD.DCC (26 pp.). La segunda oración, en castellano, es la de Gaspar González de Candamo: Sermón de honras fúnebres

115 Manuel Antonio Valdés, M. A. 1799: 10-18, pp. 137-144. Miércoles, 18 de junio de 1800. Ejemplar consultado en AGN de México, Reales Decretos, Año 1800, ff. 204-208. por el doctor don Gaspar González de Candamo, canónigo magistral de la Iglesia de México (48 pp.). El anónimo cronista (entiéndase Maneiro) se fija en lo más espiritual del discurso de Candamo: pide a Dios por el eterno descanso del arzobispo, de quien no se podía decir más que palabras de reverencia y colocarlo en un lugar privilegiado al lado del Altísimo, quien lo premió por sus virtudes y obediencia. Aunque sientan profunda tristeza por la muerte de tan insigne prelado, Candamo exhorta a los fieles a recobrarse de la pérdida y continuar con sus deberes, pero siempre cobijados en la palabra de Dios. Presenta pasajes bíblicos para que los desconsolados entendieran que la resignación era el mejor camino para lograr la paz interior.

Por su parte, el periodista de la citada Gazeta de México del miércoles, 18 de junio de 1800, dedicada íntegramente a informar sobre los últimos días y los funerales del arzobispo Alfonso Núñez de Haro, es más detallista. Tiene dos claras partes. Una primera destinada a relatar la vida y última enfermedad del arzobispo. ${ }^{116}$

La crónica de la Gazeta tiene una segunda parte, cuyo fin es poner de relieve las virtudes de Núñez de Haro y el dolor que los feligreses tienen por su pérdida, remitiendo, en aras de la brevedad, al panegírico que debía de decir Gaspar González Candamo en su oración fúnebre en el noviembre siguiente: "Los oradores que han de anunciar al público oportunamente sus virtudes, demostrarán con los más mínimos coloridos y con la mayor elocuencia lo que deja de decirse". ${ }^{117}$

El gacetero subraya que, "después de una larga y penosa enfermedad, en que por más de un año y tres meses lo probó y ejercitó el Señor como al Justo", reunió al cabildo para dictarle un último razonamiento "elocuentísimo y animado con todo el juego de la caridad apostólica". Aunque esta función era en secreto, fue divulgada por uno de los asistentes, el virrey Félix Berenguer de Marquina. ${ }^{118} \mathrm{~A}$ los dos días pidió con instancia la Extremaunción y se despidió dando todo tipo de consejos, concluyendo que "pocos ejemplares habrá de una muerte tan serena y tan alegre". ${ }^{119}$

Ciertamente el periodista de la Gazeta competía con Candamo, en ensalzar las cualidades del fallecido arzobispo, con un lenguaje más directo, y por lo tanto más eficaz que el del magistral asturiano, quien pronunciará un panegírico demasiado engolado. La ciudad de México se esmeró en hacer unas honras fúnebres dignas al arzobispo-virrey Núñez de Haro. El contexto en el que González de Candamo preparó el discurso fúnebre puede adivinarse a través de una anotación manuscrita puesta en un margen de la misma Gazeta del 18 de junio de 1800, encuadernada por orden del virrey: "Hubo varias consultas con el Real Acuerdo sobre las honras fúnebres que habían de hacerse al cadáver, y se formó de ellas un cuaderno que se colocó en el Archivo en el ramo de virreyes". ${ }^{120}$

116 Valdés, M. A. Gazeta de México: 203-204. Día 18-VI-1800.

117 Ibídem.

118 Félix Berenguer de Marquina y Fitzgerald (Alicante, 1736Alicante, 30 de octubre de 1826) fue un oficial naval que, del 30 de abril de 1800 al 4 de enero de 1803, fue virrey de la Nueva España.

119 Valdés, M. A. 1799. Gazeta de México: 205-206. Día 18-VI-1800.

120 Ibídem: 208. 
El panegírico fúnebre de la muerte del arzobispo-virrey Núñez de Haro. ${ }^{121}$

El sermón que Candamo predicó en la catedral de México en las exequias de su arzobispo es, sin duda, el más protocolario de los tres que conocemos de él. Probablemente el afecto que le tuvo hizo que su aproximación a la figura del prelado careciese del análisis y de la matización que habíamos observado trece años antes en el panegírico de Carlos III. Candamo prefirió utilizar aquí todos los lugares comunes de la oratoria fúnebre, tendiendo a la hagiografía; aun así, su oración tiene una elocuencia bien dirigida a conmover a sus oyentes o lectores. ${ }^{122}$

Ya hemos visto que Núñez de Haro era una figura polémica por varias razones. Su actuación como virrey, aunque breve, fue discutida. Su participación activa en la persecución del entonces todavía ingenuo fraile dominico y después ferviente independentista, Servando Teresa de Mier, fue, como mínimo, contraproducente, ${ }^{123}$ como le comentará el experimentado fiscal de Indias, José de Cistué, al jesuita Lorenzo Hervás en carta fechada en Madrid el 3 de junio de 1800, donde se muestra partidario de "archivar" el asunto. ${ }^{124}$

Su figura se prestaba, pues, a hacer variados análisis políticos (ya que fue virrey), e históricos, ya que vivió una época de transición, por demás interesante y salpicada de hechos que luego serían determinantes, como el nacimiento claro del movimiento criollista como fuerza política de choque. Cuando ejerció el virreinato (1787) el arzobispo Núñez de Haro tuvo algún incidente con la Real Audiencia, porque ésta se negaba a que fuera su presidente. Al tomar el mando, llevó a cabo el establecimiento de un jardín botánico, con plantas que hizo traer de todas las provincias. Durante su gobierno fue planteado el sistema llamado de intendencias, propuesto por el visitador Gálvez. Trató de ayudar a la población indígena, haciendo que suprimieran los repartimientos de indios; pero sus órdenes no fueron obedecidas. Sin embargo, nada de esto se refleja en la oración de Candamo que seguidamente, aunque con brevedad, vamos a glosar.

Hemos dicho que el volumen en que está contenido el sermón de Candamo se titula Relación de la fúnebre ceremonia y exequias del Ilustrísimo [...] Dr. Don Ildefonso Núñez de Haro y Peralta, que consta de varias partes. En él aparece primero la relación de la agonía y los rituales fúnebres posteriores al deceso del arzobispo, con una narración pormenorizada de las varias ceremonias que este hecho conllevaba. Después se insertan descripciones del túmulo

\footnotetext{
121 Astorgano, A. 2013-1.

122 Zayas, G. 1991: 399-400

123 Fray Servando predicó el día 12 de diciembre de 1794 un sermón en la Colegiata de la Virgen de Guadalupe, poniendo en duda la veracidad de su leyenda ("oponiéndose á la recibida y autorizada tradición de dicha Santa Imagen"). El arzobispo Núñez de Haro acusó a Teresa de Mier de herejía y blasfemia ante el Santo Oficio y le condenó a diez años de exilio en el convento dominico de Las Caldas (Cantabria, España). Además, fray Servando fue desposeído de su grado de doctor e incapacitado a perpetuidad para el ejercicio de la enseñanza, sermones o confesiones.

124 Hervás y Panduro, L, Cartas, BNM, ms. 22996, ff. 218-221.
}

instalado en la catedral, el sermón latino que fue pronunciado por José María del Barrio, también prebendado, el 23 de noviembre de 1800 y, finalmente, el sermón castellano, a cargo de Candamo.

En efecto, el 24 de noviembre, según nos dice la Relación de los actos funerarios, "después de la misa, pronunció la oración castellana el ya dicho señor canónigo magistral Dr. Don Gaspar González de Candamo, llenando la grande expectación en que estaba el auditorio, atraído del nombre de tal orador". ${ }^{125}$ El volumen, que circuló mucho en la Nueva España y en España misma (está en muchas bibliotecas que hemos consultado), incluía también, como era costumbre, poesías laudatorias y fúnebres.

El exordio comienza con este lema, tomado del Eclesiastés, (cap. XVIII, vers. 17): "Nonne ecce verbum super datum bonum? Sed utraque cum homine justificato" (“¿No veis cómo la palabra agradable es mejor que la dádiva? Pero una y otra deben concurrir en el hombre justificado"), aludiendo al carácter humanitario y afable del arzobispo fallecido. El tema del exordio es muy similar al que escribió para las exequias de Carlos III en 1789: es un vituperio de la muerte, templado por el acatamiento a la voluntad de Dios, quien da la vida y la quita.

El vituperio a la muerte, como si ésta fuese un personaje de la comedia humana, tiene una larga tradición retórica desde los mismos principios del arte de la elocuencia. Aquí, Candamo lleva su exordio por ese camino para poder extraer al recurso toda su efectividad emotiva; apostrofa a la muerte por su crueldad y dice que ante ella sólo puede consolar la religión: "La religión sola puede y debe consolarnos en semejante fracaso, que las criaturas no son, todas ellas juntas, más que cisternas secas, que no contienen agua ninguna que pueda refrigerar los ardores del corazón, que inflamado con deseos inútiles corre ansioso tras el bien de que se siente despojado" (p. III). Más tarde, recuerda la bondad y la justicia del arzobispo, y señala que la muerte de los justos "no debe ser llorada" (p. VII).

En seguida, sin que haya una ruptura perceptible entre el exordio y las siguientes partes del discurso, se adentra en la primera: la alabanza de las cualidades más sobresalientes de Núñez de Haro: la amabilidad, la bondad y la dulzura de trato. En esta parte, de corte lírico-poético, Candamo diserta sobre esas cualidades, que también eran deseadas por muchos reformadores eclesiásticos. Parece que se había hecho necesario insistir en que el obispo debía ser dulce y de amable trato, puesto que así lo recomendaban Gregorio Mayans, el inquisidor Felipe Bertrán, el arzobispo Tomás Lorenzana y el propio Núñez de Haro. Los tiempos se inclinaban más por la persuasión que por el castigo y por la severidad, hecho que también explicaría, con otros elementos que no son del caso, el progresivo pero imparable declive de la Inquisición. El elogio de la dulzura de trato del arzobispo, ocupa tres cuartas partes de la oración fúnebre de Candamo. Para éste, no es únicamente necesario hacer el bien sino también acompañarlo con buenas palabras. Para el magistral asturiano, el sabio es siempre benevolente, mientras que el necio es áspero: “Como el rocío templa los ardores del sol, del mismo 
modo la dulzura de las palabras suaviza los corazones", dice citando las Escrituras. Dios escoge, para apacentar a sus ovejas, a los hombres más dulces. ${ }^{126}$

Entramos luego en el acostumbrado recuento de la bondad de los antecedentes del fallecido: Candamo repasa la nobleza de sus padres, ${ }^{127}$ la excelente educación que le dieron (mencionando su paso por el Colegio de Españoles de San Clemente de Bolonia), y toca el inevitable tópico de la precoz sabiduría del futuro prelado. El magistral elogia también -llevando el agua a su molino- los conocimientos de hebreo y Sagradas Escrituras que cultivó Núñez de Haro. Afirma que su sabiduría no fue mundana sino religiosa y teológica Es interesante ver cómo Candamo interpreta todavía la religión como verdad y la ciencia como mentira, a pesar de que él mismo sintió curiosidades científicas en la Universidad de Salamanca: "Como el señor Haro no se contentase con aquella falsa y contrahecha sabiduría [...] que consiste solamente en una vana posesión de las ciencias, puso todos sus conatos en adquirir la que [...] es un tesoro infinito para los hombres. La ciencia hincha, pero la caridad edifica" (p. XII).

Esa verdadera ciencia hace, según Candamo, que el hombre pueda enseñar lo que sabe a los demás, sin sentir envidia ni rencores. Estas cualidades hacían que el arzobispo fuese amado, respetado y obedecido con placer, sin que en ningún momento se sintiera pesado su servicio: "Ver y oír al señor Haro bastaba para que fuese amado; tratarle cautivaba las voluntades" (p. XIII). Conquistó el amor de los mexicanos, cuya diócesis gobernó durante 27 años: "iCuánta impresión no causaba en vuestros espíritus aqueIla vehemencia y aquella dulzura de sus elocuentísimas oraciones!" (p. XV).

Todos los cristianos están obligados por su religión a ser benevolentes, dulces y amables con sus semejantes, pero aún más lo están los obispos, que son ejemplo para todos. Antes, dice Candamo, se persuadía por el terror, como Dios mismo fue terrible en los primeros tiempos. Pero luego cambió el terror por la dulzura, y el obispo debe ser el que con mayor evidencia exhiba esta cualidad: "No se seguirán grandes daños a la Iglesia de Jesucristo porque el obispo no ayune [...], no se extenúe con los rigores de la penitencia; pero la aspereza de un ánimo desabrido le ocasionará a sí mismo y a los prójimos grandes calamidades" (p. XVII).

Algunos eminentes teólogos como San Pablo o San Agustín insistieron en que el obispo debía hacerse respetar por su feligresía, y aconsejaron con frecuencia dureza, o al menos, firmeza en el trato, pero mayor respeto inspira quien es dulce que quien pretende, con malos modos, hacerse respetar por la fuerza o con aspereza.

La segunda y última parte del sermón sirve para pasar revista, con rapidez y sin entrar en mayores detalles, en los bienes que el arzobispo dejó a su diócesis. Candamo habla de la epidemia de viruelas que en 1779 asoló el país, y cuenta cómo el arzobispo se ocupó personalmente del aprovisionamiento del hospital de San Andrés, que llegó a

\footnotetext{
126 Zayas, G. 1991: 402.

127 Descendía de los Peralta, de Alarcón (Cuenca), y de los Núñez, de Chinchilla (Albacete).
}

tener 800 camas. Como virrey, dice Candamo no sin apartarse un tanto de la verdad a tenor de los incidentes arriba comentados, fue tan acertado y prudente "que no dejó que desear a sus habitantes, sino el que hubiese sido virrey por muchos años" (p. XXII).

El magistral asturiano, siempre preocupado por la educación, como otros reformistas, menciona varias de las cosas que Núñez de Haro consiguió hacer en esta área: la reforma de los estudios del Seminario Tridentino, la reedificación del colegio de niñas de San Miguel de Belén, la de la casa de los expósitos, la creación del Hospicio de Pobres, tan en la línea de la política carolina de beneficencia en España, el establecimiento de varias escuelas de primeras letras, etc.

Especial atención le merecen la modernización de los estudios de Teología y, con ella, la superación de las interminables disputas bizantinas, por medio del mejor conocimiento de las fuentes y de los textos originales, abandonando las siempre plúmbeas interpretaciones escolásticas, contra las que el canónigo asturiano había luchado en la Universidad de Salamanca (1775-1786). Su discurso va también dirigido contra el casuismo y el probabilismo jesuitas, y defiende "la verdadera teología, el estudio de las Santas Escrituras, el dogma y la moral tomadas en sus fuentes y la Historia y la disciplina de la Iglesia, precedidas de una filosofía digna de tan glorioso nombre. Seguid, jóvenes afortunados, seguid con ardor la carrera que habéis emprendido; despreciad las voces de los necios, que, confundiendo la ilustración con la impiedad, y la religión con la ignorancia, no dejarán de intentar, disfrazados con la capa de piadosos, apartaros de la senda en que os puso vuestro sabio padre" (p. XLVIII).

El otro punto que resalta es el de la reforma del clero, en la que propició la creación del Colegio de Tepotzotlán ${ }^{128}$ para sacerdotes desviados o dudosos en su conducta, donde se recluían o eran recluidos para reencontrar el "verdadero camino". Este colegio correccional importa "para la reforma del clero y para el bien espiritual de los fieles", pues es un "puerto seguro del sacerdocio, que se acoge a él contra las borrascas del mundo, y tabla de salvamento en que consiguen la vida los desgraciados que han podido naufragar" ( $p$. XLVIII).

El orador concluye lamentando, como hizo en el exordio, la muerte de tan gran benefactor, y también imaginando su apoteosis:

"Ya le veo, ya le veo con tu soberano auxilio, ya le veo semejante en todo al otro sumo sacerdote Onías ${ }^{129}$ difunto, que mostraste a Judas Macabeo, bondadoso de corazón, lleno de dulzura y afabilidad, de aspecto venerable,

128 Cabría señalar que se trataba del antiguo noviciado de los jesuitas, que tras la expulsión de éstos pasó a manos del arzobispo de México. Núñez de Haro convirtió el colegio de Tepotzotlán en el Seminario de Instrucción, Retiro Voluntario y Corrección, una especie de cárcel para eclesiásticos.

129 Onías III, Sumo Sacerdote de Jerusalén (177-174 a. C.), hijo y sucesor de Simón II, ensalzado por el libro de Daniel como "Príncipe Mesías" (Dn 9, 25) y "Príncipe de una Alianza" (Dn 11, 22), se apareció a Judas Macabeo antes de la Batalla de Adasá (2M 15, 11-16). En el 177 a. C., el sirio Heliodoro, tesorero de Seleuco IV, intentó expoliar el tesoro del Templo de Jerusalén, lo que sólo pudo ser evitado mediante la intervención divina. 
modesto de costumbres y agradable en sus palabras, levantando las manos a Dios para rogar por su pueblo" ( $p$. XLVIII).

En el cabildo del 25 de noviembre se inserta el "Certificado de las honras del Ilmo. Señor obispo Dr. don Alonso Núñez de Haro", que recoge la actividad más relevante de Candamo a lo largo de este año. ${ }^{130}$

En resumen, como hemos señalado, este tercer y último sermón publicado por Candamo es, sin duda, el menos interesante, porque carece del análisis crítico y de la matización psicólogica que habíamos observado en los dos anteriores. El magistral prefirió utilizar aquí todos los lugares comunes de la oratoria fúnebre, tendiendo a la hagiografía. Aún así, su oración fúnebre, no de mala factura, y acertada en sus citas, siempre bien escogidas, tiene una elocuencia bien dirigida a conmover a sus oyentes o lectores. ${ }^{131}$ No obstante, el párrafo largo con acumulación de oraciones coordinadas hace la lectura lenta y farragosa.

A partir de la publicación de esta oración no volvemos a tener noticias literarias de Candamo hasta su muerte, acaecida el 16 de mayo de 1804.

\section{CONCLUSIONES}

No es fácil resumir los rasgos característicos de la contradictoria personalidad del teólogo ilustrado Candamo. No obstante debemos resaltar sus afanes reformistas puestos al servicio del más fiel regalismo a lo largo de toda su vida, en la Universidad de Salamanca (1775-1786), militando sin ambages en el mismo bando que su amigo Meléndez Valdés, y en América, adscribiéndose claramente en el «partido de los españoles», entendiendo por tal el conjunto de personas nacidas en España que rodeaban a sus obispos, pero que todavía no estaba enfrentado claramente al criollista en los tiempos inmediatamente anteriores al inicio de las rebeliones independentistas. ${ }^{132} \mathrm{Al}$ respecto es significativa su cercanía con los obispos Antonio Alcalde y Juan Ruiz de Cabañas y con la familia "española" Sánchez-Leñero, en Guadalajara, y su presidencia de la Cofradía de los Oriundos de Asturias y su amistad con el arzobispo-virrey Núñez de Haro y con el canónigo-bibliógrafo José Mariano Beristáin, en México.

Fuera del aula libró la batalla en el bando de la minoría reformista con ciertos actos que ponen de manifiesto de una manera más clara su afán de renovación y su carácter luchador, regalista y hasta antiescolástico y filojansenista en sus planteamientos filosófico-teológicos, como cuando el claustro de la Universidad de Salamanca le encargó redactar un curso de filosofía en 1780, junto a otros tres catedráticos

\section{ACCM, Libro 60, ff. 85v-86.}

131 Zayas, G. 1985: 23; Zayas, G. 1991: 405.

132 Según Rodolfo Aguirre, "tanto en el cabildo catedralicio como alrededor de él se había constituido un tejido de relaciones e influencias capaz de generar grupos poderosos, no solamente por la alta investidura y prestigio de que gozaban los prebendados, sino también por la gran influencia y poder de decisión que tenían en la distribución de curatos, cátedras y canonjías, por no mencionar sus grandes atribuciones en sede vacante. Alrededor del cabildo se formaban grupos clientelares y de ahijados que confiaban en formar parte del mismo algún día". Aguirre, R. 2004-1: 189. progresistas, ${ }^{133}$ adaptado a los planteamientos ilustrados porteriores a expulsión de los jesuitas, siguiendo el Plan de Estudios de 1771, recordado con cierto orgullo en el currículum de 1797 por el canónigo asturiano: "Fue comisionado por el claustro pleno de dicha universidad [de Salamanca] para censurar el nuevo curso de Filosofía, mandado formar por el Supremo Consejo de Castilla". ${ }^{134}$ Es evidente que el enérgico carácter del reformista asturiano lo impulsó a participar en diversas polémicas, en contra del "espíritu de partido" de los catedráticos de las Órdenes religiosas, cuyo dominio en el claustro era el verdadero e insalvable obstáculo que se oponía a cualquier reforma que se propusiese, a pesar del apoyo decidido del fiscal Campomanes. ${ }^{135}$

En 1783, el asturiano fue de nuevo protagonista en otra polémica universitaria: la de los grabadores de Salamanca. Candamo, Juan Justo García, Antonio Alva y Judas Tadeo Ortiz (todos ellos profesores del ala progresista, amigos de Meléndez Valdés) fueron los encargados de controlar a los artesanos encargados de esculpir los tipos destinados a una futura imprenta universitaria, que jamás llegó a funcionar, por la oposición del sector inmovilista del claustro. ${ }^{136}$

No cabe duda de que estas polémicas perjudicaron a Candamo y le granjearon la enemistad de muchos catedráticos tradicionalistas. Esta antipatía se reflejó en los continuos fracasos que sufrió en las oposiciones, que normalmente se distribuían siguiendo un orden tácito. A Candamo nunca le tocó el turno y este hecho nos indica el grado de animadversión que existía contra su persona en el grupo mayoritario cercano a los teólogos de las órdenes religiosas.

Es evidente que el enérgico carácter del magistral asturiano lo impulsó a participar en diversas polémicas a favor del reformismo borbónico, poniéndose incondicionalmente al servicio de Campomanes, quien supo recompensar su fidelidad nombrándolo académico correspondiente de la Real Academia de la Historia ${ }^{137}$ y concediéndole una canonjía de gracia en América, porque en la Península los teólogos tradicionalistas, vinculados a las distintas órdenes religiosas, lo tenían vetado para una cátedra de Teología o canonjía magistral, su auténtica vocación.

La amistad entre Candamo y Meléndez Valdés hace tiempo que está reconocida, a partir de las profundas afinidades ideológicas que tenían. ${ }^{138}$ Una amistad similar, con los matices derivados del menor trato directo, es la que Candamo tuvo con Jovellanos, como demuestran sus actividades en el seno de la Real Academia de la Historia

133 Sobre el fracaso de este proyecto véase el capítulo "La penosa historia, desde 1772 hasta 1793, de un Curso de Filosofía, encargado por el Consejo a la Universidad de Salamanca", en Cuesta Dutari. 1974, vol. II: 7-93; Astorgano, A. 2007: 265-271; Astorgano. 2013-1: 350-361.

134 Candamo. 1797-1.

135 AGS, Gracia y Justicia, leg. 945. "Informe de Campomanes sobre la decadencia de la Universidad de Salamanca, 18 de octubre de 1785".

136 AUS, Libro de Claustros, 243, f. 170v. El asunto de la imprenta y de los grabadores es sumamente complicado y puede verse en AHN, Consejos, leg. 5463, Exp. 23, y también Demerson. 1971, vol. I: 210-213 y Cuesta Dutari. 1974, vol. I: 556.

137 Candamo fue elegido miembro correspondiente de la Academia de la Historia, presidida y dominada por Campomanes, el 6 de febrero de 1785. Astorgano, 2011-2: 36-39.

138 Demerson, G. 1971: vol. I, 89-90. 
(1785-1786) y, sobre todo, ayudando económicamente al Instituto Asturiano cuando más lo necesitaba (1804). A ambos asturianos los unía el deseo de regenerar la sociedad española mediante una enseñanza de calidad, anhelo compartido por el protector de ambos, el poderoso Campomanes. Ciertamente no hay ninguna duda sobre la actitud reformista-ilustrada de Candamo. Partidario convencido de las reformas de los políticos del reinado de Carlos III, tuvo serios enfrentamientos con los contrarios a las mismas en el claustro de la Universidad de Salamanca, como sabemos. En América continuó siendo un funcionario regalista que se movió en el seno de las élites españolistas, sin que se le conozca ningún tipo de polémicas o enfrentamientos. Como excelente orador sagrado, desgraciadamente sólo podemos atisbar la modernidad y reformismo de su pensamiento sociopolítico y religioso (cercano al jansenismo) a través de tres sermones, una muy pequeña muestra de los muchos que debió componer.

Igual que sus amigos Meléndez Valdés, Jovellanos y Campomanes, el magistral asturiano es un buen ejemplo de lo que significó la versión española de la Ilustración, por su alejamiento de cualquier extremo, su moderación y sentido práctico, y por su realismo político. Trabajador nato (estuvo opositando hasta los 45 años), y siempre reformista, estaba dispuesto a ir a las comisiones más difíciles (recuérdense su gobierno [1790-1792] en la fronteriza diócesis de Nuevo León [Monterrey] y la agregación a la diócesis de Guadalajara de los curatos, algunos montañosos, ${ }^{139}$ de la diócesis de Valladolid de Michoacán [1795]). No dudó en abandonar su vitalicia cátedra de la Universidad de Salamanca, donde tenía la sensación de perder el tiempo, y emigrar a América, donde podía trabajar con más libertad, y no solo para medrar profesionalmente. Beristáin halló en Candamo una exquisita literatura, unas recomendables prendas y su capacidad para gobernar un obispado. ${ }^{140}$

En el plano estrictamente literario, sus sermones presentan un cristianismo íntimo y sereno, con una ortodoxia firmemente apoyada en el conocimiento directo y profundo de las Escrituras, como demuestran las precisas y numerosas citas. La estructura sigue los cánones de los discursos cerrados, así el Sermón de honras de Núñez de Haro se abre y cierra con la idea de que el cristiano solo halla consuelo en la Religión. Formalmente dominan las figuras retóricas de la anáfora, la comparación, la metáfora sencilla y la alegoría, sin las exageraciones del neobarroco. Sin embargo, el lector actual desearía una menor amplitud en los párrafos, que ciertamente hacen lenta y pesada la lectura.

Al final de su vida se insertó plenamente en la minoría dirigente de "españoles" de la Nueva España, como el más ferviente regalista (hubiera llegado a obispo, si no hubiese fallecido a los cincuenta años), pero nunca se obsesionó por el poder político. Nos queda más bien la imagen de un clérigo venerable, defensor de un sincero cristianismo bíblico

139 La Barca es una población ribereña del lago de Chapala, Zapotlán está en un valle (aunque incluía algunas localidades serranas); la parroquia de Colima, cercana al Océano Pacífico, abarcaba sobre todo llanuras costeras.

140 Beristáin de Souza, J. M. 1816: vol. II, 36. que se nos antoja filojansenista, porque resume los anhelos ideológicos de un par de generaciones de españoles de la segunda mitad del siglo XVIII, que creyeron en el progreso a través de la armonía, lejos de radicalismos traumatizantes revolucionarios, razón por la que los teólogos conservadores de la Universidad de Salamanca nunca lo admitieron en las estructuras de poder en su Facultad. En la Nueva España, el canónigo asturiano se puso incondicionalmente al servicio de los obispos de Guadalajara Antonio Alcalde y Juan Cruz Ruiz de Cabañas, del arzobispo Núñez de Haro y de los virreyes de México. Otros, como sus amigos Jovellanos y Meléndez, prefirieron impulsar las reformas en España, acercándose al poder madrileño, y terminaron pagando cara su osadía con sendos destierros en una época de revoluciones.

\section{BiBLIOGRAFÍA}

Aguirre Salvador, R. 2003. El merito y la estrategia: clérigos, juristas y médicos en Nueva España. México, D.F.: UNAM, Centro de Estudios Sobre la Universidad.

Aguirre Salvador, R. 2004-1. "El acceso al alto clero en el arzobispado de México, 1680-1757", Fronteras de la Historia 9 (2004): 179-203. Disponible en http://www.icanh.gov.co/ recursos_user/documentos/editores/202/Fronteras_09/ Fronteras_09_05_articulo.pdf.

Aguirre Salvador, R. 2004-2. "Los límites de la carrera eclesiástica en el Arzobispado de México, 1730-1748", en Aguirre Salvador, Carrera, linaje y patronazgo, México: UNAM/CESU/Plaza y Valdés.

Aguirre Salvador, R. 2007. "El clero secular de Nueva España. Balance historiográfico y perspectivas de investigación", Anuario del Centro de Estudios Históricos "Prof. Carlos S. A. Segreti", Vol. 7, № 17 (2007): 229-250.

Aguirre Salvador, R. 2008. "De las aulas al Cabildo Eclesiástico. Familiares, amigos y patrones en el Arzobispado de México, 1680-1730", Tzintzun: Revista de Estudios Históricos, №. 47 (2008): 75-114.

Aguirre Salvador, R. 2010. "Los juristas de la Universidad de México y la Curia arzobispal", en Facultades y grados: $X$ Congreso Internacional de historia de las Universidades Hispánicas (Valencia, Noviembre 2007), Mariano Peset Reig (coord.), Vol. I: 35-58.

Aguirre Salvador, R. 2012. "José Lanciego, arzobispo de México, y el clero regular durante la transición eclesiástica del reinado de Felipe V, 1712-1728", Fronteras de la historia: revista de historia colonial latinoamericana, Vol. 17, №. 2 (2012): 75-101.

Alarcos García, E. 1926. “Meléndez Valdés en la universidad de Salamanca", Boletín de la Real Academia Española 13: 160-161.

Arenas Frutos, I. 2004. Dos arzobispos de México, Lorenzana y Núñez de Haro, ante la reforma conventual femenina: (1766-1775). León: Universidad de León.

Astorgano Abajo, A. 1999. "El paso de Jovellanos y Meléndez Valdés por el Ministerio de Gracia y Justicia (1798)", Revista de Estudios Extremeños 55-3: 995-1052. 
Astorgano Abajo, A. 2001-1. "El conflicto de rentas entre las cátedras de humanidades y Meléndez Valdés (17801784)", Cuadernos del Instituto "Antonio de Nebrija" 4: 11-90.

Astorgano Abajo, A. 2001-2. "Meléndez Valdés y el enfrentamiento entre los catedráticos del Colegio de Lenguas (1780-1784)", en Real Academia de Extremadura de las Letras y las Artes, El Humanismo Extremeño. Estudios presentados a las Cuartas Jornadas organizadas por la Real Academia de Extremadura en Trujillo en 2000: 263-291. Trujillo: Academia de Extremadura.

Astorgano Abajo, A. 2004. “El regalismo borbónico y la unión de hospitales: la lucha de Meléndez Valdés en Ávila", en E. Serrano Martín (coord.), Congreso internacional "Felipe V y su tiempo": vol. II, 37-64. Zaragoza: Institución "Fernando el Católico".

Astorgano Abajo, A. 2007. D. Juan Meléndez Valdés. El Ilustrado. Badajoz: Diputación de Badajoz, Colección "Biografías Extremeñas".

Astorgano, Abajo, A. 2009. "Hervás y Panduro y sus amigos ante la Mexicanidad", en Milena Koprivitza Acuña, Manuel Ramos Medina, Cristina Torales Pacheco, José María Urkía, Sabino Yano Bretón (eds.), Ilustración en el mundo hispánico: preámbulo de las Independencias: 201254, Tlaxcala: Gobierno del Estado de Tlaxcala / Universidad Iberoamericana.

Astorgano Abajo, A. 2011-1. “Esbozo biográfico de Gaspar González de Candamo, amigo íntimo de Meléndez Valdés", en J. Álvarez Barrientos y J. Herrera Navarro (eds.), Para Emilio Palacios Fernández.25 estudios sobre el siglo XVIII español: 365-386. Madrid: Fundación Universitaria Española / Real Sociedad Bascongada de Amigos del País.

Astorgano Abajo, A. 2011-2. “Jovellanos y el magistral ilustrado Gaspar González de Candamo, amigos de Meléndez Valdés". Boletín Jovellanista, Año XI, Núm. 11 (Gijón, 2012): 13-70.

Astorgano Abajo, A. 2012-1. "Las aventuras del canónigo González de Candamo, íntimo amigo de Meléndez Valdés, en Nueva España (1787-1804)". Revista de Estudios Extremeños tomo 68-3: 1257-1322.

Astorgano Abajo, A. 2012-2. "El Colegio Menor Universitario Nuestra Señora de la Vega de Salamanca durante la llustración (1771-1808)", en Luis E. Rodríguez-San Pedro y Juan Luis Polo Rodríguez (eds.), Imagen, contextos morfológicos y universidades, Miscelánea Alfonso IX: 349397. Salamanca: Centro de Historia Universitaria Alfonso IX.

Astorgano Abajo, A. 2012-3. "González de Candamo, Gaspar", en Diccionario biográfico Español. Madrid: RAH.

Astorgano Abajo, A. 2013-1. "La literatura de González de Candamo, amigo íntimo de Meléndez, y su ilustrado panegírico de Carlos III". Boletín de la Real Academia de Extremadura 21: 321-408.

Astorgano Abajo, A. 2013-2. "La visita de 1774 del Colegio universitario Nuestra Señora de la Vega de Salamanca", CIAN-Revista de Historia de las Universidades 16/1: 13-50.

Astorgano Abajo, A. 2014. "El pleito de jurisdicciones sobre la capacidad para obtener beneficios eclesiásticos entre el obispo González Pisador y la Colegiata de San Isidoro de León (1783-1787)", Studium Ovetense: Revista del Instituto Superior de Estudios Teológicos del Seminario Metropolitano de Oviedo 39: 13-112.

Beristáin de Souza, J. M. 1816-1821. Biblioteca Hispanoamericana Septentrional. México: Impta. de la Viuda de Jáuregui (2 2 ed. México: UNAM, Biblioteca del claustro de sor Juana, Instituto de estudios y documentación históricos).

Blanco. P. L. 1798. Noticia de las antiguas y genuinas colecciones canónicas inéditas de la Iglesia española. Madrid: Imprenta Real.

Brading, D. 1994. Una Iglesia asediada: el obispado de Michoacán, 1749-1810, México: FCE.

Bustamante. C. Ma 1836 . Suplemento a la historia de los tres siglos de México durante el gobierno español escrita por el padre Andrés Cavo, tomo III, México.

Cerdán, F. 2002. “Actualidad de los estudios sobre oratoria sagrada del Siglo de Oro (1985-2002). Balance y perspectivas", Criticón, no 84-85 (2002), p. 9-42.

Cienfuegos-Jovellanos González-Coto, F. de B. 2004. Memorias del artillero José María Cienfuegos Jovellanos (1763-1825) (Gobernador y Capitán General de la isla de Cuba y de la Florida). Gijón: Fundación Foro Jovellanos.

Concilio III Provincial Mexicano, celebrado en México el año de 1585, confirmado en Roma por el Papa Sixto V, y mandado observar por el gobierno español en diversas Reales Ordenes, ed. bilingüe, notas y apéndice de Basilio Arrillaga, publicado por Mariano Calvan Rivera, México: Eugenio Maillefert y Cía., 1859, 607-CLII-22 pp.

Crisólogo, Pedro, 1985. Sermones (obra completa), Barcelona: Alpha SA.

Crisólogo, Pedro, 1998. Homilías escogidas, Madrid: Editorial Ciudad Nueva.

Cuesta Dutari, N. 1974, El maestro Juan Justo García, Salamanca: Universidad, 2 vols.

Connaughton, B. 1987. "La Iglesia y la Ilustración tardía en la intendencia de Guadalajara: el discurso ideológico del clero en su contexto social", Estudios de Historia Novohispana 9: 159-188.

Chinchilla Pawling, P. 2004. De la compositio loci a la República de las letras: predicación jesuita en el siglo XVII novohispano, México: Universidad iberoamericana.

Chocano, M. 2000. La fortaleza docta. Élite letrada y dominación social en México colonial (siglos XVI-XVII), Barcelona: Bellaterra.

Chust Calero, M. 2009. «Los diputados novohispanos y la Constitución de 1812». En Memoria de las revoluciones en México. Vol. 5. México: RGM Medios. pp. XXI-LV.

Dávila Garibi, J. I. 1984. Biografía de un gran prelado. El Exmo. e Ilmo. Sr. D. Juan Cruz Ruiz de Cabañas y Crespo, México: Editorial Jus (7a edición).

Dávila Garibi, J. I. 1963. Apuntes para la Historia de la Iglesia en Guadalajara, vol. III, México: Editorial Cultura.

Demerson, G. 1971. Don Juan Meléndez Valdés y su tiempo (1754-1817). Madrid: Taurus, 2 vols. 
Estrada de Gerlero, E. I. 1993. "Carlos III y los estudios anticuarios en Nueva España", en Xavier Moyssen y Louise Noelle (eds.), 1492-1992. V centenario: arte e historia: 63-92. México: Universidad Nacional Autónoma de México.

Escamilla, I. 1999. José Patricio Fernández de Uribe (1742-1796). El cabildo eclesiástico de México ante el Estado borbónico, México: CONACULTA, Dirección General de Publicaciones, Facsimilar disponible en línea: http://www. filosofia.org/aut/002/esc1999.htm.

Farris, N. M. 1995. La corona y el clero en el México colonial (1579-1821). México: Fondo de Cultura Económica.

Flores, M. de. 1806. "Resumen histórico de la vida, conducta pastoral y política del Excmo. e Illmo... Sr. Dr. D. Alonso Núñez de Haro y Peralta", prólogo en Alfonso Núñez de Haro, 1806-1807. Sermones escogidos, pláticas espirituales privadas y pastorales, anteriormente impresas en México..., con el retrato del autor y un resumen histórico de su vida, 3 vols. Madrid: Hija de Ibarra.

Franco-Paredes, C., Lammoglia, L., Santos-Preciado, J. I. 2004. "Perspectiva histórica de la viruela en México", Gaceta médica de México, vol. 140, no 3 (México may. / jun. 2004), pp. 2-29.

Ganster, P. 1991, “Miembros de los Cabildos Eclesiásticos y sus familias en Lima y la ciudad de México", en Pilar Gonzalbo (coord.), Familias Novohispanas. Siglos XVI a XIX: 149-162. México: El Colegio de México-Centro de Estudios Históricos.

García Aguilar, I. 2009. "Religión y tipografía: la protesta de fe en el impreso novohispano", en Filiberto Felipe Martínez Arellano-Juan José Calva González (compiladores), Memorias del XXVI Coloquio de investigación bibliotecológica y sobre la información: 221-245. México: UNAM, Centro Universitario de Investigaciones Bibliotecológicas.

García Moratalla, P. J. 1987. Villagarcía a mediados del siglo XVIII (1749-1761), Albacete: Diputación, IEA.

García Pérez, A. 2002. "Miguel Martel, un filósofo reformador y liberal", en Congreso Internacional. Orígenes del liberalismo, CD, Salamanca.

García Pérez, A. 2013. La escuela ilustrada salmantina. Miguel Martel (1754-1835), Madrid: UNED.

García Puron, M. 1984. México y sus gobernantes, vol. I. México: Joaquín Porrúa.

Giménez López, E. 2008. Misión en Roma: Floridablanca y la extinción de los jesuitas, Murcia: Universidad.

González de Candamo, G. 1789. Sermón de honras del Rey nuestro Señor D. Carlos tercero, que de Dios goze, predicado en la santa iglesia catedral de la ciudad de Guadalaxara en la Nueva Galicia, el día 28 de julio de 1789 por el Dr. D. Sin impresor.

González de Candamo, G. 1797-1. Relación impresa de méritos y ejercicios literarios del Dr. D. Gaspar González de Candamo, fechada en México el 2 de agosto de 1797. Son ocho hojas, conservadas en el Archivo General de la Nación de México (AGN), Indiferente Colonial, Caja 2182, Exp. 34.
González de Candamo, G. 1797-2. Sermón predicado el día 15 de enero de 1797, en la solemne profesión de religiosa de coro que, con el nombre de sor Juana María de Guadalupe, hizo doña Juana María Josefa Sánchez Leñero, en el monasterio de religiosas dominicas de Santa María de Gracia de la ciudad de Guadalaxara..., Guadalaxara: Oficina de D. Mariano Valdés Téllez Girón.

González de Candamo, G. 1801. Sermón de las honras, predicado en las solemnes que celebró la Santa Iglesia Metropolitana de México el día 24 de noviembre del año 1800, a la buena memoria de su difunto arzobispo el Excelentísimo Señor Don Alonso Núñez de Haro y Peralta, virrey, gobernador y capitán general que fue de esta Nueva España, (sin lugar ni fecha, pero México, 1801).

Guitarte Izquierdo, V. 1992, Episcopologio Español (1700-1867), Castellón de la Plana: Ayuntamiento.

Gutiérrez Lorenzo, Mạ P. 2006. “Universitarios alcalaínos en la Nueva España", en E. González y L. Pérez (coords.), Permanencia y cambio. Universidades hispánicas 15512001. vol. I: 397-418. México: UNAM.

Herrejón Peredo, C. 2002. "Sermones novohispanos", en Raquel Rodríguez (coord.), Historia de la literatura mexicana: desde sus orígenes hasta nuestros días, vol. II: 425453. México: UNAM, siglo XXI.

Herrejón Peredo, C. 2003. Del sermón al discurso cívico: México, 1760-1834, Zamora: El Colegio de Michoacán.

Herrejón Peredo, C. 2004. "la oratoria en nueva España", Relaciones, tomo 57, volumen 15 (2004): 51-72.

Híjar Ornelas, T. 2003. Fray Antonio Alcalde y su legado a la posteridad, México: Instituto Cultural Ignacio Dávila Garibi.

Híjar Ornelas, Tomás. 2013. Silencio y oración litúrgica. La comunidad de monjas dominicas de Santa María de Gracia de Guadalajara a 425 años de su fundación, Guadalajara: Arquidiócesis de Guadalajara.

Konrad, H. W. 1995. Una hacienda de los jesuitas en el México colonial: Santa Lucía, 1576-1767, México: Fondo de Cultura Económica.

Lobdell, J. E y Owsley, D. 1974. "The origin of syphilis», Journal of Sex Research, vol. 10 (agosto de 1974): 50-79.

López, T. 1987. Relaciones geográfico-históricas de Albacete (1786-1789) de Tomás López, Albacete. Edición de Fernando Rodríguez de la Torre y José Cano Valero.

Luengo, M. 1767-1814, Diario de la expulsión de los jesuitas de los dominios del Rey de España, al principio de sola la provincia de Castilla la Vieja, después más en general de toda la Compañía, aunque siempre con mayor particularidad de la dicha provincia de Castilla (años 1767-1814). Ms. en Archivo del Santuario de Loyola.

Maneiro, J. L. 1801. Relación de la fúnebre ceremonia y exequias del ilustrísimo y excelentísimo señor doctor don Ildefonso Núñez de Haro y Peralta, arzobispo que fue de esta santa Iglesia Metropolitana de México, virrey y capitán general de esta Nueva España, caballero gran Cruz de la Real y Distinguida Orden Española de Carlos III, etc., etc., dispuesta por un presbitero de este arzobispado, de orden y 
por mandato del ilustrísimo señor arcediano y cabildo, sede vacante, México: Imprenta de Ontiveros.

Martel, M. 1805. Oración fúnebre que a la buena memoria del doctor don Gaspar González de Candamo, canónigo magistral de la Santa Iglesia de México, dijo en el día 20 de diciembre de 1805 el doctor don Miguel Martel, catedrático de Filosofía Moral. Salamanca: Imprenta de don Juan Vallegera, impresor de la Universidad.

Medina, J. T. 1908. La imprenta en México, 1539-1821, México, UNAM, 1989 (1a edición de 1908-1912, 8 vols.).

Meléndez Valdés, J. 2004, Obras Completas. Madrid: Ediciones Cátedra, Bibliotheca Áurea. Edición, introducción, glosario y notas de Antonio Astorgano Abajo.

Melgosa Oter, Óscar Raúl. "Entre el progreso y la tradición: un sermón ilustrado para las exequias de Carlos III". Hispania Sacra 126: 661-695.

Muriel, J. 1991. Hospitales de la Nueva España. México: Universidad Nacional Autónoma de México.

Núñez de Haro, A. 1806-1807. Sermones escogidos, pláticas espirituales privadas y pastorales, anteriormente impresas en México..., con el retrato del autor y un resumen histórico de su vida, 3 vols. Madrid: Hija de Ibarra. Contiene una biografía de Manuel de Flores.

Perdigón Castañeda, J. K. 2011. "De hábito y corona”, en La conservación de las coronas de monjas del Museo de Arte Religioso ex convento de Santa Mónica, Puebla, México: Instituto Nacional de Antropología e Historia.

Obregón, Ignacio de. 1784, Práctica del púlpito para instrucción de los nuevos predicadores, manifestada según el estado presente de la Oratoria, en tres discursos. Panegírico moral y doctrinal, ahora nuevamente aumentada con un tratado sobre el sermón de misterio y varias reflexiones críticas. Para cuya obra y su inteligencia se pone una disertación preliminar. Por el P. Ignacio de Obregón, de los Clérigos Menores, lector jubilado en Sagrada Theología. Segunda edición. Madrid: Oficina de Pedro Marín.

Pérez Martín, A. 1979. Proles Aegidiana III. Los colegiales desde 1601 a 1800. Bologna: Publicaciones del Real Colegio de España.

Rivera Cambas, M. 1872. Los gobernantes de México. Galería de biografías y retratos de los virreyes... desde don
Hernando Cortés hasta Benito Juárez, tomo I. México: Viuda de Murguía e Hijos.

Rodríguez Laso, N. 2006. Diario en el viage a Francia e Italia, Zaragoza: Institución Fernando el Católico, Real Sociedad Económica Aragonesa.

Romero Delgado, J. 1991. Aportaciones pedagógicas desde la formación del clero. Los seminarios reformados por Ruiz de Cabañas. Huelva: Cuestiones Pedagógicas.

Rubio Gil, A. 1968. "Alonso Núñez de Haro”, en Calderón Quijano, J. A. (coord.), Los virreyes de Nueva España en el reinado de Carlos III: 361-403. Sevilla: Escuela de Estudios Hispano-Americanos.

Ruiz García, V. 2013. Las naves de las Cortes (1808-1812). El último servicio de la Marina de la llustración, Madrid: Silex.

Saint Clair Segurado, E. Ma. 2005. Expulsión y exilio de la provincia jesuita mexicana (1767-1820). Alicante: Universidad.

Torales Pacheco, Ma. C. 2010. "El canto del cisne: el bibliógrafo José Mariano Beristáin”, en Milena Koprivitza Acuña, Manuel Ramos Medina, María Cristina Torales Pacheco, José María Urkía Echave, Sabino Yano Bretón (Eds.), La guerra de conciencias: monarquía o independencia en los mundos hispánico y lusitano: 444-462. Tlaxcala: Gobierno del Estado de Tlaxcala.

Torres Mena, J. 1878. Noticias conquenses, Madrid: Imprenta de la Revista de Legislación.

Torres Puga, G. 2010. Opinión pública y censura en Nueva España. Indicios de un silencio imposible (1767-1794). México: Colegio de México, Centro de Estudios Históricos.

Trabulse, E. 1985. Francisco Xavier Camboa: un político criollo en la llustración mexicana (1717-1794), México: El Colegio de México-Centro de Estudios Históricos.

Valdés, M. A. 1799. Gazeta de México 10-4. México: Imprenta de Don Mariano Zúñiga y Ontiveros.

Zayas de Lille, G. 1985. "Vida y andanzas de un ilustrado asturiano: Gaspar González de Candamo», Astura: Nuevos cartafueyos d'Asturias 4: 13-23.

Zayas de Lille, G. 1991. Introducción al estudio de la oratoria sagrada novohispana en la segunda mitad del siglo xVIII y primera década del siglo XIX. Barcelona: Universidad de Barcelona. 